\title{
Diluted Seawater and Ammonia-N
} Tolerance of Two Mangrove Crab Species. New Insights to Understand the Vulnerability of Pristine Islands Ecosystems Organisms

\author{
Laura Mégevand ${ }^{1 *}$, Dimitri Theuerkauff2, Claire L'Épine', Sophie Hermet', \\ Emmanuel Corse ${ }^{1,3}$, Thibaut L'Honoré ${ }^{3}$, Jehan-Hervé Lignot ${ }^{1}$ and Elliott Sucré1,3 \\ ${ }^{1}$ MARBEC, CNRS, IFREMER, IRD, Univ Montpellier, Montpellier, France, ${ }^{2}$ Station de Recherche Océanographiques et \\ Sous-Marines (STARESO), Calvi, France, ${ }^{3}$ Centre Universitaire de Formation et de Recherche de Mayotte (CUFR), Dembeni, \\ France
}

\section{OPEN ACCESS}

Edited by:

John Cockrem,

Massey University, New Zealand

Reviewed by:

Benny K. K. Chan,

Academia Sinica, Taiwan

Marco Fusi,

Edinburgh Napier University,

United Kingdom

P. Ragavan,

Physical Research Laboratory, India

*Correspondence:

Laura Mégevand

laura.megevand@protonmail.com

Specialty section:

This article was submitted to

Ecophysiology,

a section of the journal

Frontiers in Ecology and Evolution

Received: 19 December 2021

Accepted: 11 February 2022

Published: 03 March 2022

Citation:

Mégevand $L$, Theuerkauff $D$,

L'Épine C, Hermet S, Corse E, L'Honoré T, Lignot J-H and Sucré E

(2022) Diluted Seawater and Ammonia-N Tolerance of Two

Mangrove Crab Species. New

Insights to Understand the Vulnerability of Pristine Islands

Ecosystems Organisms.

Front. Ecol. Evol. 10:839160.

doi: 10.3389/fevo.2022.839160
Mangrove ecosystems are the primary receptors of anthropogenic pollution in tropical areas. Assessing the vulnerability of these ecosystems can be expressed, among other indicators, by studying the health of 'ecosystem engineers'. In this study, mangrove forests facing opposing anthropogenic pressures were studied (i) in the uninhabited island of Europa (Mozambique Channel), considered as a pristine ecosystem, and, (ii) on the island of Mayotte, facing regular domestic wastewater discharges. Using an ecophysiological approach, the effects of diluted seawater (DSW) and increased ammonia-N were studied for two fiddler crab species: Gelasimus tetragonon (GT) on the island of Europa and Paraleptuca chlorophthalmus (PC) on the island of Mayotte. Osmoregulation curves and osmoregulatory capacity were determined along with $\mathrm{O}_{2}$ consumption rates after a $96 \mathrm{~h}$ exposure period. Histological analyses were also carried out on two important metabolic organs: the hepatopancreas and the posterior gills. Results indicate that both crab species are good hyper-hypo-osmoregulators but only PC can maintain its osmoregulatory capacity when exposed to ammonia-N. Oxygen consumption is increased in GT after $96 \mathrm{~h}$ of exposure to ammonia- $\mathrm{N}$ but this does not occur in PC. Finally, a thickening of the gill osmoregulatory epithelium was observed after $96 \mathrm{~h}$ in PC when exposed to ammonium but not in GT. Therefore, the two species do not have the same tolerance to DSW and increased ammonia-N. PC shows physiological acclimation capacities in order to better manage nitrogenous enrichments. GT did not show the same physiological plasticity when exposed to ammonia- $\mathrm{N}$ and could be more at risk by this kind of stress. These results along with those from other studies regarding the effects of domestic effluents on mangrove crabs are discussed. Therefore, the greater vulnerability of organisms occupying pristine ecosystems could induce major changes in mangrove functioning if crabs, that are engineer species of the ecosystem, are about to reduce their bioturbation activity or, even, disappear from the mangrove forests.

Keywords: Crustacea, pristine ecosystems, biomarkers, metabolism, ammonia-N, mangrove 


\section{INTRODUCTION}

Ecological and ecosystem vulnerability assessment may represent a valuable tool in biodiversity risk management (De Lange et al., 2010). From the definition of Ippolito et al. (2010), ecosystem vulnerability may represent "the potential of an ecosystem to modulate its response to stressors over time and space, where that potential is determined by characteristics of an ecosystem vulnerability that include many levels of organization." Ecosystem vulnerability assessment may be expressed with a level of potential impact related to a certain stressor in a given environment: "the actual status of a polluted ecosystem or community represents the response of a (more or less) pristine ecosystem or community to a specific stressor or to multiple stressors" (De Lange et al., 2010). The authors, thus, state that combining the assessment of vulnerability of a pristine ecosystem or community with the actual status allows obtaining crucial information for risk management.

Among vulnerable ecosystems, mangrove forests that thrive intertidal areas are typically subjected to a variety of stressors, both natural and anthropogenic. These include high levels of pollutants and nutrients, severe hypoxia, high water turbidity, and fluctuations in temperature and salinity. Mangroves are significant ecosystems to study given their ecological importance in tropical areas. They accomplish a wide range of key ecosystem functions such as carbon storage, nutrient and global carbon cycling, provide breeding, recruitment, nursery and feeding areas both terrestrial and aquatic fauna (Nagelkerken et al., 2008; Amaral et al., 2009; Cannicci et al., 2009; Lugendo and Kimirei, 2021). Also, mangrove forests form a buffer zone protecting the shoreline against erosion and watershed (Zhang et al., 2012; Ouyang and Guo, 2016).

Located at the land-sea interface, mangroves are the receptacle of anthropogenic activities such as aquaculture, agriculture, urbanization, tourism or coastal pollution (Thomas et al., 1996; Alongi, 2002; Xiang et al., 2020; Lugendo and Kimirei, 2021).

Nitrogen inputs and the altered global cycle of $\mathrm{N}$ are one of the most important concerns about anthropogenic presence and activities (Vitousek et al., 1997). Human alterations of the nitrogen cycle can lead, amongst others, to changes in the composition and functioning of estuarine and nearshore systems, with accelerated losses of biological diversity (Nixon, 1995; Nixon et al., 1996; Vitousek et al., 1997). It has been predicted that tropical regions will receive the most dramatic increases in reactive $\mathrm{N}(\mathrm{Nr})$ inputs over the next few decades (Zhu et al., 2005; Galloway et al., 2008). In this context, our study aims at comparing some features of ecosystem vulnerability in both pristine and anthropized mangrove ecosystems.

Europa island $\left(22^{\circ} 20^{\prime} \mathrm{S}, 40^{\circ} 22^{\prime} \mathrm{E}\right)$ is the southernmost island of the Mozambique Channel. It is considered a pristine ecosystem as there is no permanent human settlement, making it a prime candidate for marine conservation (O'Donnell et al., 2017). Europa island is a low-lying (7 m elevation), coral island of $28 \mathrm{~km}^{2}$ surrounded by sand dunes. A shallow lagoon, almost empty at low tide, is located on the north-western part of the island. It is fringed with 626 ha of mangrove forest (Boullet, 2014; Juhel et al., 2019).
Mayotte island $\left(12^{\circ} 50^{\prime} \mathrm{S} 45^{\circ} 08^{\prime} \mathrm{E}\right)$ is a tropical island $\left(374 \mathrm{~km}^{2}\right)$ situated in the Comoros Archipelago, in the northern part of the Mozambique Channel. On this island, the mangrove forest covers about 700 ha of the territory (Jeanson et al., 2019). Large ecological gradients are encountered in Mayotte rivers and mangroves, one of the main anthropogenic pressures being the lack of connection between households and the sewage systems. Therefore, domestic wastewater is often discharged directly into rivers and mangroves (Herteman, 2010; Vasselon et al., 2017; Capdeville, 2018). Furthermore, the island of Mayotte possesses a fast growth of its human population, especially over the last two decades resulting in an exponential increase in anthropogenic pressures and degradations of its marine environment (Pusineri et al., 2014).

Studying ecosystem vulnerability in response to stressors must take into consideration indicators of ecosystem functioning, including early warning, diagnostic and retrospective indicators. Aquatic organisms including crustacean species, are frequently studied as early warning indicators of changes in environmental conditions (Burger, 2006; Ungherese and Ugolini, 2009). Some ecological functions provided by these species, such as ecosystem engineering, have also been identified (Brodie et al., 2018) as key elements to incorporate into conservation planning (see Coggan et al., 2018 for a review). Ecosystem engineers are species whose actions have "significant impacts" upon the physical structure of their habitat and the organisms that live in them (Jones et al., 1994). Amongst them, we find burrowing mangrove fiddler crabs, considered as ecosystem engineers through their bioturbation activity (Kristensen, 2008; Penha-Lopes et al., 2009; Kristensen et al., 2012). Their activity briefly consists in burying, macerating and ingesting litter as well as actively digging and maintaining burrows in the sediment (Giddins et al., 1986; Emmerson and McGwynne, 1992; Dittmann, 1996; Lee, 1997; Kristensen and Alongi, 2006).

We chose to study two ecologically, morphologically and phylogenetically proximate species of Ocypodids fiddler crabs: Paraleptuca chlorophthalmus (PC) from the island of Mayotte and Gelasimus tetragonon (GT) from the island of Europa (Figure 1). As fiddler crabs, these two species are mainly characterized by a sexual dimorphism where female possess two small feeding claws when males possess one enlarged claw (up to $50 \%$ of total bodyweight). PC distribution range is restricted to the East African province of the Indian Ocean Subrealm of which it is endemic, whereas GT is the fiddler crab with the largest distribution range. It is widespread in the Indian Ocean and also in the Pacific Ocean (Figure 1) (Rosenberg, 2020). Only one observation of GT has been reported in Mayotte Island (Bouchard et al., 2013). PC has also been observed once in Europa Island (Poupin et al., 2012). We did not confirm this observation and the DNA sequencing analysis performed on the crabs collected on Europa Island did not reveal any representative of this species (see Supplementary Material). These two species are the most abundant crab species living in semi-open canopy habitats situated near tidal rivulets of the two studied mangroves. In these two areas, a high density of burrows (that originates from bioturbation activity) is observed. These habitats are the first receptors of anthropogenic spillages in the island of Mayotte. 
Salinity variations throughout freshwater inputs and high levels of nutrients are two key stressors in such context. On the island of Europa, rainfall is the only source of freshwater, with a mean annual rainfall of $540 \mathrm{~mm} /$ year and a long dry period of 7 months in a semi-arid climate (Boullet, 2014; Lambs et al., 2016). Therefore, GT lives under strong marine influence, mostly in seawater and oligotrophic conditions. On the island of Mayotte, 24 permanent rivers reaching the sea have been listed (Lapègue, 1999), with a watershed area ranging from 2 to $23 \mathrm{~km}^{2}$ (Lagarde et al., 2021). Therefore, PC is frequently experiencing salinity variations and osmotic changes under mesotrophic or eutrophic conditions, especially in anthropized areas.

In habitats with frequently changing environmental conditions (such as mangrove forests), organisms are exposed to multiple stressors that can neutrally, synergistically or antagonistically interact (Piggott et al., 2015; Renault et al., 2018). In order to maintain functional homeostasis, phenotypic adjustments may be expressed during the life history of an individual, ranging from physiological adjustments (acclimation) (Teets and Denlinger, 2013) to phenological changes and range shifts (Chuine, 2010; Briscoe et al., 2012; Renault et al., 2018). In some cases, these exogenous factors can generate physiological evolutionary changes because of genetic modifications (adaptation). This study does not aim to determine any potential environmental adaptation in the event that different sensitivities are observed between crab populations, and this should remain a working hypothesis only.

Considering these elements, we chose to study physiological endpoints on different levels of biological organization to assess the potential effects of salinity variations and short-term exposures to ammonia-N on the two crab species. Physiological biomarkers such as osmoregulatory capacity (the difference between hemolymph osmotic pressure and that of the external medium, OC), oxygen consumption and histological changes have been widely studied and proved to be informative proxies of crustacean responses to environmental changes such as salinity variations and ammonia-N inputs (Lignot et al., 2000; Gillikin et al., 2003; Ortega et al., 2017; Theuerkauff et al., 2018a,b; Ros et al., 2021). Resting metabolic rate is also considered as physiologically relevant (Ikeda, 2016; Borges et al., 2018) to assess the potential effects of an osmotic chock or ammonia- $\mathrm{N}$ exposure on crabs, independently from a potential locomotor or escape behavior.

Therefore, could GT and PC show different physiological tolerances to basic anthropogenic pressures, here: salinity reduction and high ammonia- $\mathrm{N}$ inputs? The working hypothesis is that vulnerability to diluted seawater and ammonia- $\mathrm{N}$ inputs must be different for the two species. Specifically: (1) PC could have a good tolerance capacity to reduced salinity and increased ammonium input within a short-term acclimation period; (2) GT, that is mainly recorded in stable environments, i.e., rarely exposed to eutrophic water and rarely to diluted seawater (Crane, 1975; Weis and Weis, 2004), could be vulnerable to anthropogenic discharges inducing salinity decrease; (3) there should be deleterious effects of Ammonia-N on osmoregulatory processes (aggravating factor) for both species since ammonia- $\mathrm{N}$ is known to disrupt physiological processes such as osmoregulation, immunology, acid/base balance and gas exchange in Decapod crustaceans (Weihrauch et al., 2004; Romano and Zeng, 2013).

In the present study, crabs were collected from Europa (GT) and Mayotte (PC) mangroves and were artificially exposed to diluted seawater (5 ppt) and Ammonia-N (10 mg. $\left.\mathrm{L}^{-1}\right)$, a proxy of anthropogenic presence through an environmental concentration. Several biomarkers were considered in order to: (i) define the salinity tolerance range of the two species (osmolality curves), (ii) understand whether eutrophication can have an impact on the crab ability to maintain its hydromineral balance (osmoregulatory capacity), and, (iii) determine whether short-term acclimation (oxygen consumption and histological analyses) can occur to cope with eutrophication. If GT was found to be vulnerable to freshwater and Ammonia-N, what would be the consequences in terms of vulnerability to anthropogenic pressure for the pristine mangroves of the island of Europa? What could the consequences be in terms of risk assessment?

\section{MATERIALS AND METHODS}

\section{Study Sites \\ Europa Island}

The sampling site is mainly constituted of shrubby Rhizophora mucronata on coral mud with a sandy-silty texture, in an almost open canopy (Figure 2), near tidal channels and rivulets. The absence of freshwater inflows induces no transfer of nutrient or ions from inland to the mangrove (Lambs et al., 2016). High concentrations of nitrogen and phosphorus can be found in this Island on seabirds nesting sites due to amounts of guano, but the chosen sites in this study were not concerned (Zubia et al., 2016).

\section{Mayotte Island}

The study site is located in Boueni bay $\left(12^{\circ} 55^{\prime} 1^{\prime \prime} \mathrm{S}, 45^{\circ} 9^{\prime} 23^{\prime \prime} \mathrm{E}\right)$ in the mangrove of Malamani, extending along both sides of a freshwater stream. On this site, vegetation structure is mainly represented by Ceriops tagal and $R$. mucronata facies, along with A. marina and Bruguiera gymnorhiza species. This open habitat presents no canopy cover, a large temperature gradient and regular water immersion/emersion, depending on the season, tides and time of the day. Malamani is part of the Chirongui area in the bay of Boueni, which had a human population density of $310 \mathrm{hab} . / \mathrm{km}^{2}$ in 2017.

A total of 30 crabs (15 from Europa and 15 from Mayotte) used during experiments were randomly chosen for DNA sequencing to confirm their taxonomical identification through a classical barcoding process (see Supplementary Material).

\section{Animal Collection and Acclimation}

Male and female GT and PC (the same number for each sex) were collected in April 2019 and March 2020, respectively, in the mangroves of Europa and Mayotte (Malamani area) (see Figure 2 for the sampling site). All animals were hand collected at low tide when crabs are active and out of their burrows. They were placed into individual bags or boxes in order to minimize stress and fights during transport to the laboratory 


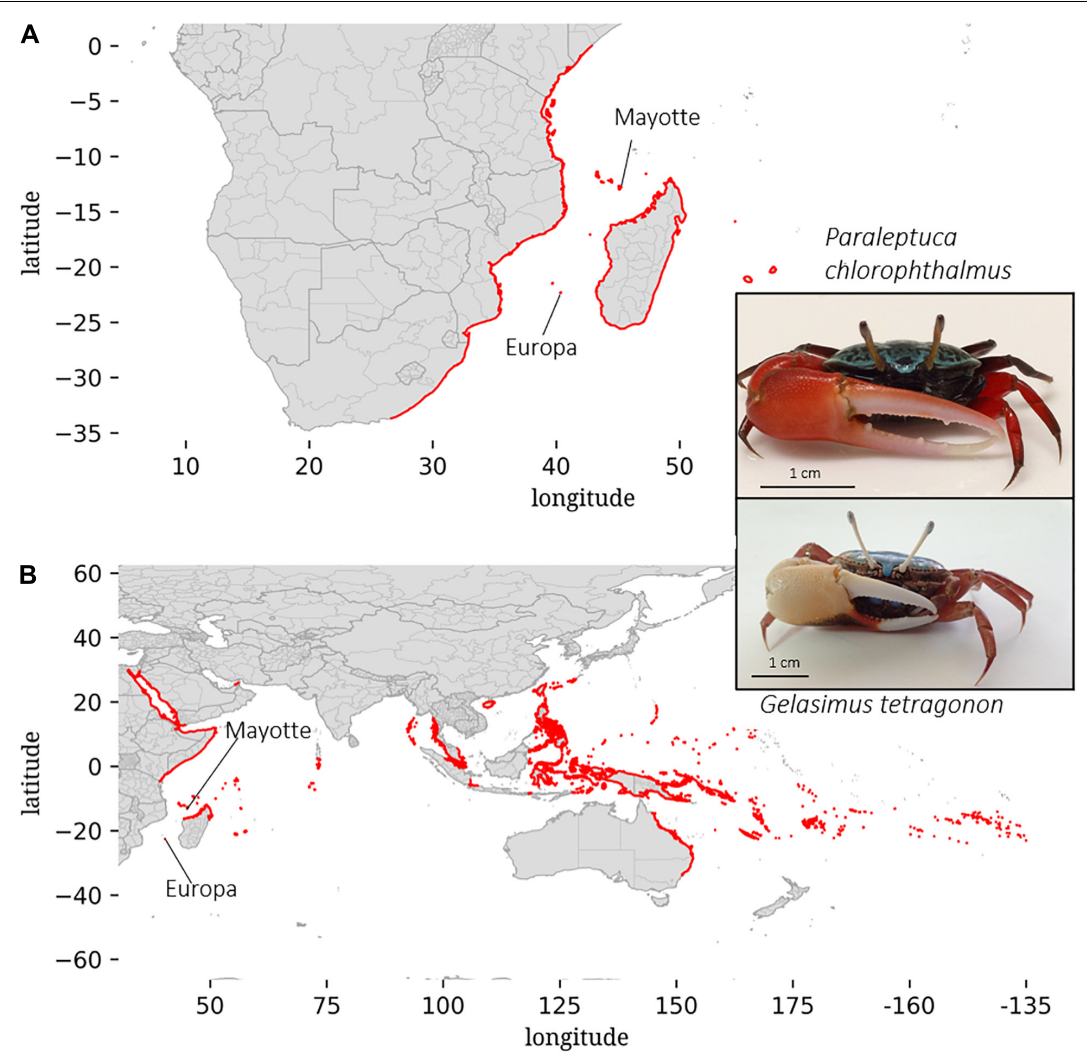

FIGURE 1 | Geographical ranges (in red) and pictures of the two studied species: Paraleptuca chlorophthalmus (A) and Gelasimus tetragonon (B). Data was generated from the cybertaxonomy database described in Rosenberg (2014) and from the website: www.fiddlercrab.info.

(either the field laboratory on Europa Island, or the CUFR marine laboratory at the University Center of Mayotte). Animals ( $\sim 130$ for PC, $\sim 100$ for GT) were placed for 3 days for acclimation in individual boxes containing natural filtered seawater $(\sim 33 \%$ salinity; 1,050 mOsm. $\left.\mathrm{kg}^{-1}\right)$, under a natural photoperiod (12 h light: $12 \mathrm{~h}$ dark) and without feeding prior to experimentation.

For the osmoregulation experiment, $\sim 100$ PC were studied ( $N=10$ per salinity) in Mayotte and $\sim 70$ GT were studied ( $N=4-8$ per salinity) in Europa Island. Sampling size was limited here due to the pristine nature of the ecosystem and legal environmental protection requirements. For the respirometry and osmoregulatory capacity, 24 crabs were studied for each species. No mortality was observed during acclimation and experimental processes for PC (Mayotte). No mortality was observed during acclimation for GT (Europa), but one female died after $72 \mathrm{~h}$ of ammonia-N exposure.

\section{Ammonia- $\mathrm{N}$ Exposure and Experimental Conditions}

Three different experimental conditions were performed: some crabs were maintained in seawater $(\sim 33 \mathrm{ppt})$, others were transferred to diluted seawater $(\sim 5 \mathrm{ppt})$ or to $10 \mathrm{mg} . \mathrm{l}^{-1}$ ammonia-N solution (hereafter noted, respectively, SW, DSW and $\mathrm{N}$ exposure). This solution was prepared by adding $1 \mathrm{mMol}$ of ammonium chloride (Sigma, United States) to diluted seawater
( $\sim 5 \mathrm{ppt})$. Ammonia-N was chosen as experimental treatment because the ionized form of ammonia-N $\left(\mathrm{NH}_{4}^{+}\right)$is the major component of domestic WW (Capdeville et al., 2018; Mégevand et al., 2021, submitted). This condition refers to total ammonia (ammonia-N). It represents the sum of unionized ammonia $\mathrm{NH} 3$ and ionized ammonia $\mathrm{NH}^{+}$(Haywood, 1983; Lemarié et al., 2004; Bermudes and Ritar, 2008). The ammonia-N concentration was chosen on the basis of concentrations that may be released by treatment plants in Mayotte (Herteman, 2010). It corresponds to a sub-lethal concentration for a fiddler crab species such as Uromastyx princeps, adults sharing similar size and morphology with P. chlorophthalmus (Azpeitia et al., 2013). Ammonia-N exposure solutions were replaced every day. Salinity of SW and diluted seawater (DSW) were tested every day and readjusted if needed.

\section{Osmolality Curves}

To determine osmolality curves, crabs were exposed at different salinities with 4-8 crabs per salinity for GT, and 8-10 crabs per salinity for PC. Salinity ranged from DSW $\left(\sim 4.5 \mathrm{ppt}, \sim 135 \mathrm{mOsm} \cdot \mathrm{kg}^{-1}\right)$ to concentrated SW ( $\sim 51 \mathrm{ppt}$, $\sim 1,510$ mOsm. $\left.\mathrm{kg}^{-1}\right)$. Animals were maintained in isolated boxes for a minimum of $72 \mathrm{~h}$, which is sufficient time for osmoregulation to be achieved in such estuarine crustacean species (Lovett et al., 2001; Rivera-Ingraham et al., 2016). 


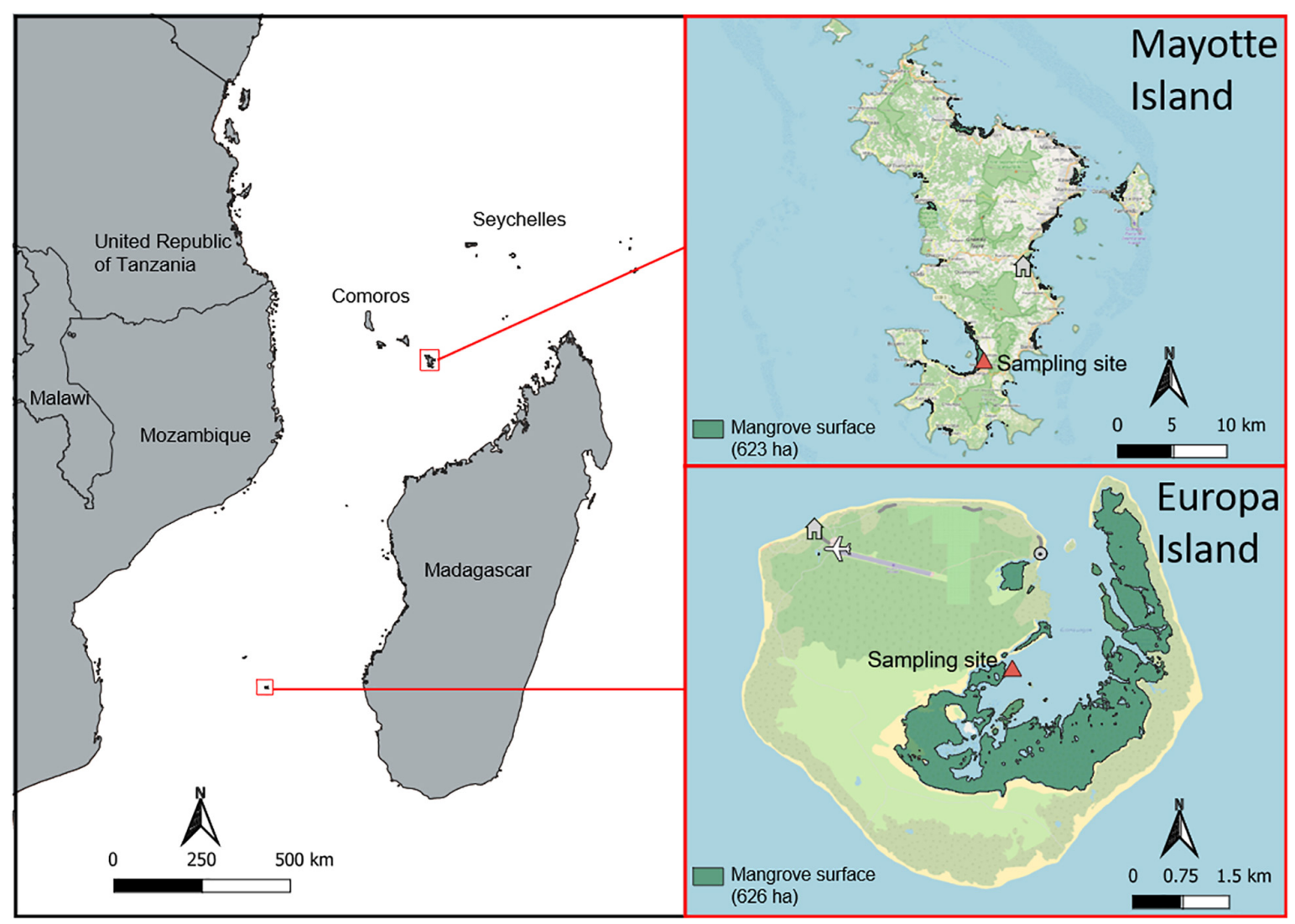

FIGURE 2 | Localization of Mayotte Island and Europa Island in the Mozambique Channel with the sampling sites.

After this period, a hemolymph sample was taken using a $0.1-0.5 \mathrm{ml}$ hypodermic syringe with the needle inserted between the cephalothorax and the third and fourth periopod. Osmotic pressure (OP) of the hemolymph samples was immediately quantified in duplicate by freezing point depression osmometry (Model 3320, Advanced Instruments, Inc., Norwood, MA, United States).

At the end of this experiment, animals were put back in individual boxes in aerated SW before being released into the mangrove.

\section{Oxygen Consumption Rate}

The experimental design consisted in a static, intermittent flow-through respirometry system based on Clark et al. (2013). Crabs were individually placed into $125 \mathrm{ml}$ chambers allowing them to make sporadic movements considering their size, while ensuring accurate measurements of $\mathrm{O}_{2}$ consumption. Following procedures described in Killen (2014), $\mathrm{O}_{2}$ measurements were performed using a 4-channel fiberoptic system with contactless $\mathrm{O}_{2}$ sensor spots (FireSting $\mathrm{O}_{2}$, PyroScience, GmbH, Aachen, Germany) where water oxygen content was quantified once every $5 \mathrm{~s}$.

Water-mixing within the chambers was achieved with magnetic stirrers located under $1 \mathrm{~mm}^{2}$ mesh grid to avoid too much disturbance (Rivera-Ingraham et al., 2016). Sensors were calibrated to 100 and $0 \%$ air saturation using air-saturated water and $80 \mathrm{mM} \mathrm{Na} \mathrm{SO}_{3}$ solution, respectively. Chambers were filled with a tubing system providing control SW, DSW or contaminated water from aerated, filtered and temperaturecontrolled tanks $\left(\sim 25^{\circ} \mathrm{C}\right)$. Crabs were gently introduced in the chambers and left to acclimate for $1 \mathrm{~h}$ in aerated seawater prior experiment.

Following acclimation, the system was filled with the exposure solution. A flush pump was switched on for $20 \mathrm{~min}$ to ensure proper mixing and was cut off during 40 min. During that time, the chambers were sealed. The decrease in oxygen content could be analyzed to indicate the rate of oxygen uptake. After the 40-min cycle, the pump was turned on to flush the metabolic chambers with aerated seawater (or DSW or DSW enriched with ammonia-N) during $20 \mathrm{~min}$. Due to the presence of aerobic and anaerobic microorganisms capable of degrading organic compounds and consuming $\mathrm{O}_{2}$ (Shchegolkova et al., 2016), a $20 \mathrm{~min}$ flushing was run to ensure $99 \%$ air saturation. The $40 \mathrm{~min}$ measurements allowed to make accurate $\mathrm{O}_{2}$ measurements without falling under the threshold of $70 \%$ air saturation in order to maintain aerobic metabolism and to avoid hypoxic stress (Ombres et al., 2011; Rodgers et al., 2016). O 2 measurements were taken at T-1h (SW), T1h, T24h, and T96h after exposure (SW as control treatment, DWS or DSW with ammonia-N) for all individuals ( $N=8$ per condition). This $96 \mathrm{~h}$ exposure time 
was chosen in order to better compare our results with data from the literature focused on the effects of pollutants and particularly ammonia- $\mathrm{N}$ on crustaceans. Many studies are based on the $96 \mathrm{~h}$ LC50 with environmental concentrations of ammonia- $\mathrm{N}$ and regularly include histological analyses (De Freitas Rebelo et al., 2000; Wang et al., 2003; Barbieri et al., 2016; Weihrauch and O'Donnell, 2017). Only one female GT exposed to ammonia-N died after $72 \mathrm{~h}$ of exposure.

\section{Osmoregulatory Capacity}

At the end of the $96 \mathrm{~h}$ respirometry exposure, a hemolymph sample from each animal was taken $(N=7-8$ per condition) and $\mathrm{OP}$ was assessed as described above.

\section{Sampling and Dissections}

Following the $96 \mathrm{~h}$ respirometry experiment, crabs were anesthetized and euthanized on ice for tissue sampling of the hepatopancreas, anterior and posterior gills in order to perform the histology measurements. Samples were fixed in Bouin's fixative solution for $48 \mathrm{~h}$ for histological analyses. Individual molting stage was verified through examination of an epipodite under a dissecting microscope after dissection (to avoid handlingassociated stress on the biological markers considered).

\section{Histological and SEM Analysis}

For histological analyses, posterior gills (pair 7 or 8) and small samples of the hepatopancreas were rinsed in $70 \%$ ethanol following immersion in Bouin's fixative solution for $48 \mathrm{~h}$. They were then dehydrated in a series of graded alcohols and embedded in paraffin. Tissue sections $(4 \mu \mathrm{m})$ were cut with a Microtome 2125RT Leica, then placed on Glycerin albumin precoated glass slides and deparaffinated. They were stained following Masson's Trichrome Staining Protocol (Martoja and Martoja-Pierson, 1967) using Haematoxylin Groat, Fuschine Ponceau and Aniline Blue staining solutions. Samples were examined using Leica DM6 microscope equipped with a Leica DMC 2900 and the associated software LAS X.

For the hepatopancreas analyses, pictures of the hepatopancreas for each individual were taken, each of them depicting 1-4 tubules. Images were scaled and analyzed using ImageJ software (version 1.51r). Tubules of the hepatopancreas were randomly selected for each individual. Four parameters were measured on each of those hepatopancreas tubules and, then, averaged for each individual $(N=3-8)$ : the area of the tubules, the number of vacuoles per tubule, the area of the B-cell vacuoles, the percentage of B-cell vacuolization area per tubule. Posterior gill epithelial thicknesses were measured from areas where nuclei were visible using a $40 \times$ objective (Figure 6C). Along this single-layered epithelium, cell heights were systematically measured from the base of the cuticle to the basal side of the cells facing the hemolymph lacuna. For statistical purposes, gills were divided into three sections along longitudinal (basal, central, and apical) and transversal axes (proximal, middle, and distal). For each of these areas, photographs were taken at the same magnification $(60 \times)$ using the CapturePro software. Measurements of epithelial gill thickness were then performed using Image as well.

\section{STATISTICAL ANALYSIS}

Statistical analyses were performed in $\mathrm{R}$ version 3.5.2 with Rstudio version 0.99.491 (Rstudio, Inc.), with an $\alpha$-level of 0.05 and $95 \%$ confidence intervals used to determine statistical significance in all tests. For osmoregulatory capacity and gills epithelial thickness, residuals were evaluated using ShapiroWilk and Levene's test, respectively, in order to test the data normal distribution behavior and variance homogeneity. Oneway ANOVAs were performed separately for posterior gills at each longitudinal level (apical, central, and basal) to assess potential differences of epithelial thickness between treatments (SW, DSW, and N) after $96 \mathrm{~h}$ exposure. To test potential effects of treatment on hepatopancreas parameters, we used generalized mixed-effects modeling with treatment as random effects (Manning, 2007; Zuur et al., 2013; Johnson et al., 2015) using the package glmmTMB (Brooks et al., 2017). The number of vacuoles per tubule, the mean area of the B-cell vacuoles per tubule, the percentage of B-cell vacuolization area per tubule in hepatopancreas were modeled in function of treatment (three-levels fixed factor) assuming a Gaussian distribution error with log link. Individual differences and repeated measurements among crabs and tubules were taken into account through a random intercept of tubule ID nested into crab ID. Then, type II ANOVAs (Wald chi-square test) were applied on the models using Anova function in CAR package (Fox and Weisberg, 2019). When significant effects of treatment were detected, they were investigated through pairwise comparisons using lsmeans package (Lenth, 2016) with Tukey correction. For $\mathrm{O}_{2}$ oxygen consumption, a generalized linear mixed model approach was taken assuming Gaussian distribution error with log link. Time (T-1h, T0h, T24h, and T96h) and treatment group (SW, DSW, and N) were considered as fixed factors. Crab ID was set as random factor nested within experimental tank (two tanks of exposure solution per treatment, $N=4$ per tank), which are nested within treatment group (SW, DSW, and N). Interaction terms were examined using the approach using type II ANOVA and multiple pairwise comparisons followed by Bonferroni correction. All values are represented as average \pm SEM.

\section{RESULTS}

\section{Tolerance to Salinity Variations and Osmoregulatory Capacity Under Osmotic and Ammonia-N Stress}

Both GT and PC are strong osmoregulators across the tested salinities since they can maintain a gradient of greater than $600 \mathrm{mOsm} \cdot \mathrm{kg}^{-1}$ above the ambient medium when exposed to salinities close to FW (5-10 mOsm. $\mathrm{kg}^{-1}$, Figure 3A). Both species hyper-regulated at lower salinities (hemolymph osmolality actively maintained at levels above that of DSW) and hypo-regulated at higher salinity (hemolymph osmolality maintained below that of SW). The difference between external medium and hemolymph osmolality significantly increased as salinity decreased when both species were exposed to DSW 

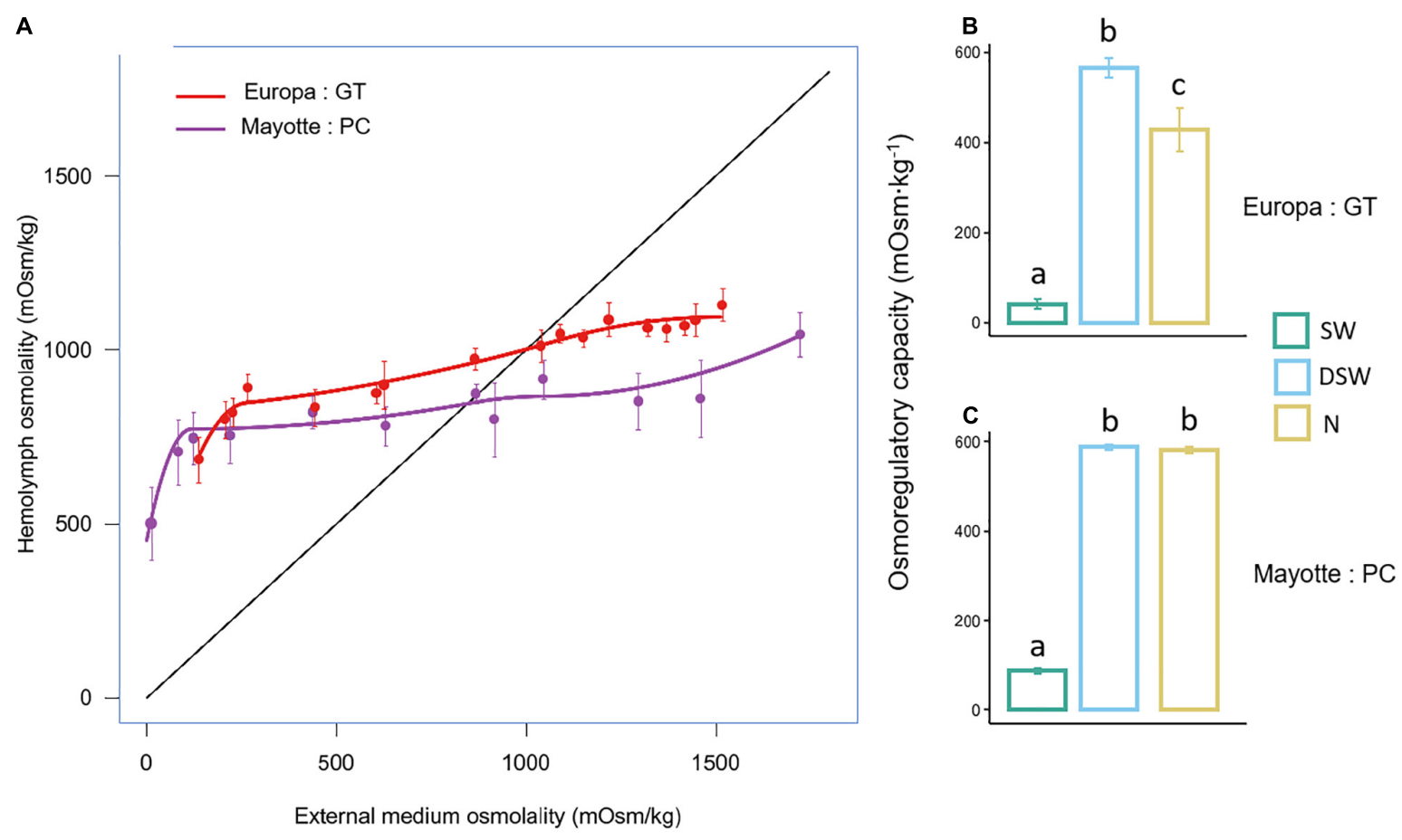

FIGURE 3 | (A) Variations in hemolymph osmolality in relation to the salinity of the external medium of GT and PC. (B,C) Osmolaregulatory capacity of GT and PC, respectively, after $96 \mathrm{~h}$ exposition to seawater (SW), diluted seawater (DSW) and $10 \mathrm{mg} \cdot \mathrm{L}^{-1}$ ammonia- $\mathrm{N}(\mathrm{N})$. Values are means $\pm \mathrm{SEM}(\mathrm{N}=7-8 \mathrm{per}$ treatment). Different letters represent statistically significant differences between treatments at $p<0.05$ obtained from a one-way ANOVA followed by Tukey post hoc comparisons.

during 96 h (Figures 3B,C). GT can maintain osmoregulatory capacity values of $\sim 50 \mathrm{mOsm} \cdot \mathrm{kg}^{-1}$ in SW and $\sim 600 \mathrm{mOsm} \cdot \mathrm{kg}^{-1}$ in DSW after $96 \mathrm{~h}$, and these values are significantly different [Figure 3B, one-way ANOVA $F(2,20)=89.44, p<0.001]$. The same results are observed in $\mathrm{PC}$ with osmoregulatory values of $\sim 100 \mathrm{mOsm} . \mathrm{kg}^{-1}$ in SW and $\sim 600 \mathrm{mOsm} \cdot \mathrm{kg}^{-1}$ in DSW [Figure 3C, one-way ANOVA, $F(2,20)=1913, p<0.001$ ]. However, a break in the curve is detected at low salinities, when it became increasingly difficult for the animals to osmoregulate. For GT, this break occurs at a higher salinity $\left(\sim 260 \mathrm{mOsm} \cdot \mathrm{kg}^{-1}\right)$ than for PC $\left(\sim 118\right.$ mOsm. $\left.\mathrm{kg}^{-1}\right)$. Moreover, PC was able to maintain the same osmoregulatory capacity in DSW with ammonia-N as in DSW (Figure 3B), whereas a significant decrease in osmoregulatory capacity is observed in GT exposed to ammonia-N compared with DSW (Figure 3C): crabs cannot maintain the haemolymph-seawater interval as in DSW.

\section{Respiration Rate Across 96 h Diluted Seawater and Ammonia-N Exposures}

Respiration rate measurements are depicted in Figure 4A for GT and Figure 4B for PC. They include temporal responses for each treatment at T-1h (SW), T0h, T24h, and T96h. In GT, a significant effect $(p<0.001)$ of exposure time on $\mathrm{O}_{2}$ consumption ( $\mu \mathrm{mol}$ $\left.\mathrm{O}_{2} \cdot \mathrm{m}^{-1} \mathrm{~g}^{-1}\right)$ was observed. The interaction between treatment and exposure time was significant $\left[\chi^{2}(6, N=31)=16.831\right.$, $p<0.01]$. Post hoc multiple comparisons on the interaction terms showed that crabs exposed to ammonia- $\mathrm{N}$ significantly increased their respiration rate after $96 \mathrm{~h}$ of exposure compared to the other time steps and with DSW (Figure 4A). No effects of the osmotic or pollutant shock was observed immediately after exposure (T0h compared to $\mathrm{T}-1 \mathrm{~h})$.

In PC, no significant effect of treatment or exposure time was found, but their interaction was significant $\left[\chi^{2}(6\right.$, $N=32)=44.5581, p<0.01]$. Post hoc multiple comparisons on the interaction terms showed that crabs exposed to SW significantly decreased their respiration rate after $96 \mathrm{~h}$ exposure compared with the other time steps (Figure 4B). Crabs exposed to DSW progressively increased their respiration rate until $96 \mathrm{~h}$ (significant difference between $\mathrm{T}-1 \mathrm{~h}$ and T96h and between T0h and T96h). At $96 \mathrm{~h}$ of exposure, a significant difference was observed between SW and DSW only.

\section{Histological Analyses}

The histology of the three main cell types of the pancreatic tubules of GT and PC is presented in Figure 5I: (1) R-cells (Restzellen, resorptive cells), the most abundant cell type in the hepatopancreas; (2) F-cells (Fibrillenzellen, fibrillar cells), which have a columnar shape and basophilic cytoplasm with an intense staining; (3) mature B-cells (Blasenzellen, blister-like cells), which are the largest cells showing large subapical vacuoles.

In GT, no effect of treatment was observed for all parameters measured in the hepatopancreas (One-way ANOVAS, Table 1, Figures 5A-D). In PC, a significant effect of treatment $(p<0.01)$ was reported regarding the percentage of B-cells vacuolization 
in hepatopancreas tubules. Tukey post hoc showed an increased vacuolization process in DSW and ammonia-N compared to SW (Figure 5 $\mathbf{H}$ ).

No effect of treatment was observed in the gills of GT across the three levels of longitudinal axis (apical, central, and basal) (one-way ANOVAs, Table 2 and Figure 6A). However, in PC, a significant effect of treatment $(p<0.0001)$ was reported at each level of the longitudinal axis (one-way ANOVAs, Table 2). Tukey post hoc tests revealed that the gill epithelium of crabs exposed to ammonium for $96 \mathrm{~h}$ was significantly thicker than those exposed to SW or DSW.

\section{DISCUSSION}

\section{Osmoregulation and Ammonia-N Excretion}

Osmoregulation is one of the key regulatory functions in aquatic organisms and represents an excellent indicator of the physiological status of crustaceans (Lignot et al., 2000). Crustaceans can be classified as strong, moderate, or weak osmoregulators depending on their capacity to tolerate low salinity and the magnitude of the hemolymph-seawater osmotic difference (Henry et al., 2012). Results indicate that both PC and GT are strong osmoregulators, but the breaking point in the osmolality curve (Figure 2) occurs at a higher salinity in GT compared to PC. Therefore, the physiological osmoregulatory limit toward low salinity for GT is reached before PC. Also, they do not share the same isosmotic point. It is higher in GT $\left(\sim 1,000 \mathrm{mOsm} \cdot \mathrm{kg}^{-1}\right)$ than in PC $(\sim 830$ mOsm. $\left.\mathrm{kg}^{-1}\right)$. Similar results have been found in sympatric fiddler crabs living under different salinity conditions in the Gulf of Mexico (Thurman, 2004). Hypersaline species such as Leptuca subcylindrica and Minuca rapax are isosmotic for media between 840 and 940 mOsm. $\mathrm{kg}^{-1}$ (26-30\%) whereas, freshwater/brackish water species such as Minuca longisignalis are isosmotic at $732 \mathrm{mOsm} \cdot \mathrm{kg}^{-1}(23 \%)$. The ability to maintain hemolymph osmolality at different environmental salinities is well correlated with the habitat of the species (Lin et al., 2002), but may also depends on the species physiology itself. Consequently, a species living near estuaries or river mouths must be highly tolerant to salinity variation (hypothesis 1 ). Ecological knowledge about habitat preferences and distribution for both studied species tend to confirm this hypothesis. GT usually inhabits exposed, lower intertidal sandy or mud flat shores fringed with mangrove forest, coral rubble or rock (Dawn and Frith, 1977; Koga et al., 2000). This species is also considered as very marine, often living on shore and never near muddy river mouths (Crane, 1975). It has the largest longitudinal range of fiddler crabs, spanning the entire breadth of the Indian Ocean and Western Pacific subrealms, as described by Rosenberg (2020). PC does not live close to the open sea but near high-tide levels on the muddy banks and flats of mangrove estuaries, close to the mouth of streams or rivulets (Crane, 1975). It is one of the dominant species living in the study site of Mayotte and is one of the three endemic species from the East Africa Province (as defined by Rosenberg, 2020). This province also comprises three other species extended into other provinces, including GT. Thus, both species can be found in Europa and Mayotte islands even if they do not share the same habitat level and salinity conditions.

Since benthic crustaceans can frequently experience elevated levels of localized ammonia- $\mathrm{N}$ when they bury in sediments with high organic contents (Weihrauch et al., 1999), it is believed that this necessitates an adaptive mechanism to remove excessive ammonia-N build-up within their hemolymph (Weihrauch et al., 2004; Romano and Zeng, 2012). Ammonia excretion has been widely studied in aquatic crustaceans and it is established that this function is intimately linked to the gills and their osmoregulatory function (see Weihrauch et al., 2004 for a complete description of the model).

The mechanisms for ammonia- $\mathrm{N}$ excretion in bimodal crabs are very diverse and complex (for a review, see Weihrauch and O'Donnell, 2017), as many membrane transporters are involved mainly in the anterior and posterior gills as well as in the antennal gland. The sodium pump $\mathrm{Na}^{+} / \mathrm{K}^{+}$-ATPase (NKA), $\mathrm{K}^{+}$-channels and $\mathrm{Na}^{+} / \mathrm{H}^{+}$exchangers (NHE) are among the key membrane proteins involved although more transporters could be at play (Masui et al., 2002, 2009; Lucu and Towle, 2003; Gonçalves et al., 2006; Freire et al., 2008; Weihrauch and O'Donnell, 2017). As already described, a number of these transporters playing a crucial role in trans-epithelial ammonia excretion are also involved in the ionoregulatory machinery (Weihrauch and O'Donnell, 2015, 2017). The best example for this is NKA, one of the key transporters responsible for energizing active $\mathrm{NaCl}$ transport processes in invertebrates and vertebrates alike (Larsen et al., 2014). The $\mathrm{NH}_{4}{ }^{+}$pump (often referred to $\mathrm{NH}_{4}{ }^{+} / \mathrm{K}^{+}$-ATPase) is equally important. However, this process reaches its limits when crustaceans are exposed to excessively high amounts of ammonia- $\mathrm{N}$, generally resulting in reduced hemolymph $\mathrm{Na}^{+}$levels (Romano and Zeng, 2012). This phenomenon has been observed in several species living under various salinity conditions: the American clawed lobster, Homarus americanus (Young-Lai et al., 1991), the Kuruma shrimp, Marsupenaeus japonicus (Chen and Chen, 1996), the burrowing crab Neohelice granulata (Rebelo et al., 1999), the freshwater crayfish Pacifastacus leniusculus (Harris et al., 2001) and the mud crab Scylla serrata (Romano and Zeng, 2007a), amongst others. We can relate these data to our results on osmoregulatory capacity: increased ammonia- $\mathrm{N}$ excretion could induce a leak in $\mathrm{Na}^{+}$ions followed by a decrease in OC for GT, but not for PC. This may suggest that PC could set-up physiological mechanisms that allow a tolerance capacity to high ammonia-N levels in DSW. However, GT could not (rapidly) mobilize such tolerance. In most Crustaceans (i.e., H. americanus and $P$. japonicus), a decrease in hemolymph $\mathrm{Na}^{+}$levels is directly linked with reduced hemolymph osmolality and/or OC, but this is not observed in the euryhaline mud crab S. serrata (Romano and Zeng, 2007a). These authors propose that this crab species relies on other mechanisms to maintain osmotic pressure even in case of $\mathrm{Na}^{+}$reduced levels, as for example, by increasing the organic osmolytes such as hemolymph free amino acids (FAA). One can hypothesis that the difference observed in OC between GT and PC may result in different abilities to excrete ammonia-N (through $\mathrm{NKA}, \mathrm{NH}_{4}{ }^{+} / \mathrm{Na}^{+}$exchanger, and/or other 


\section{Europa : G. tetragonon}
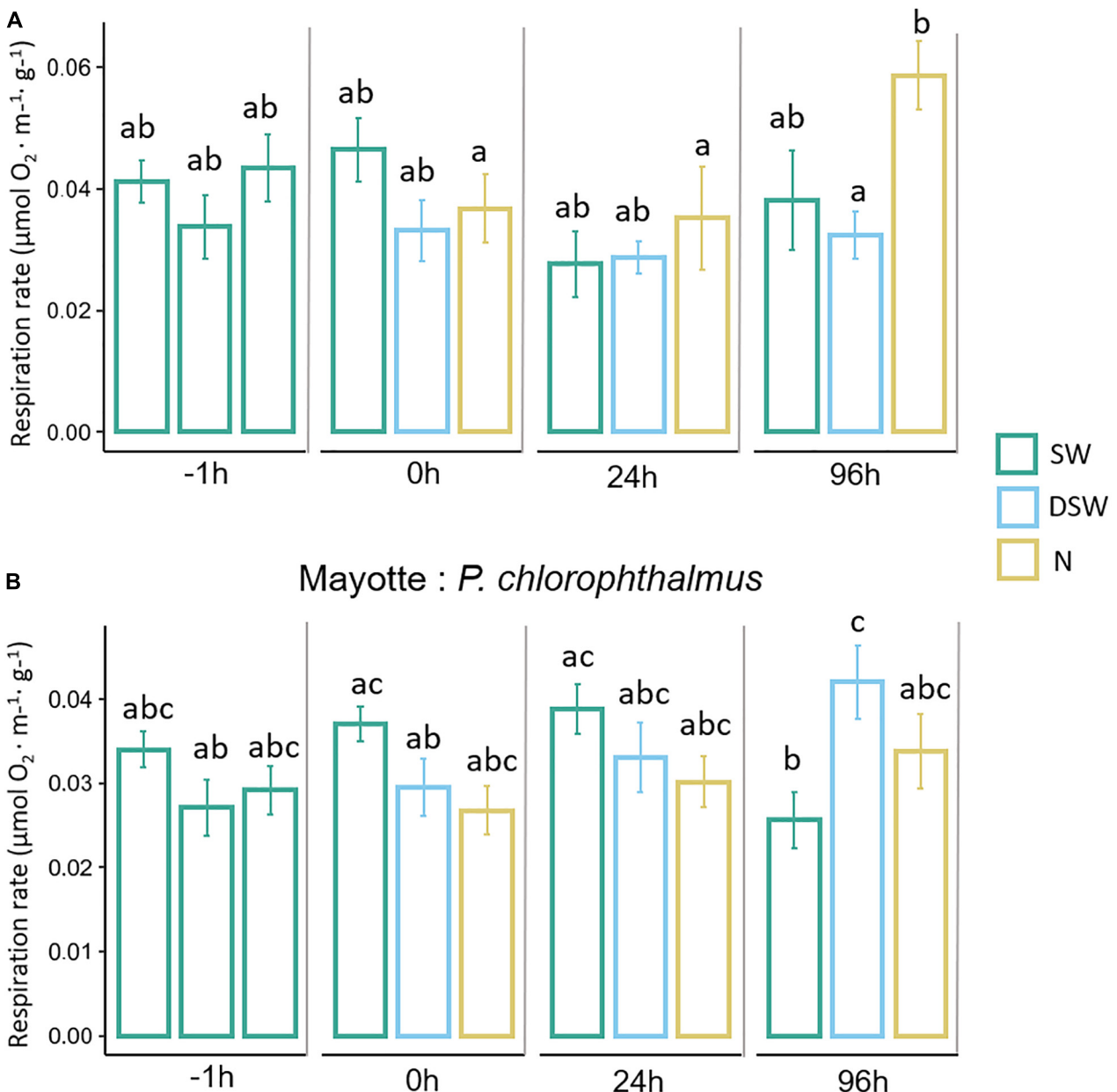

Mayotte : P. chlorophthalmus

$\mathrm{N}$

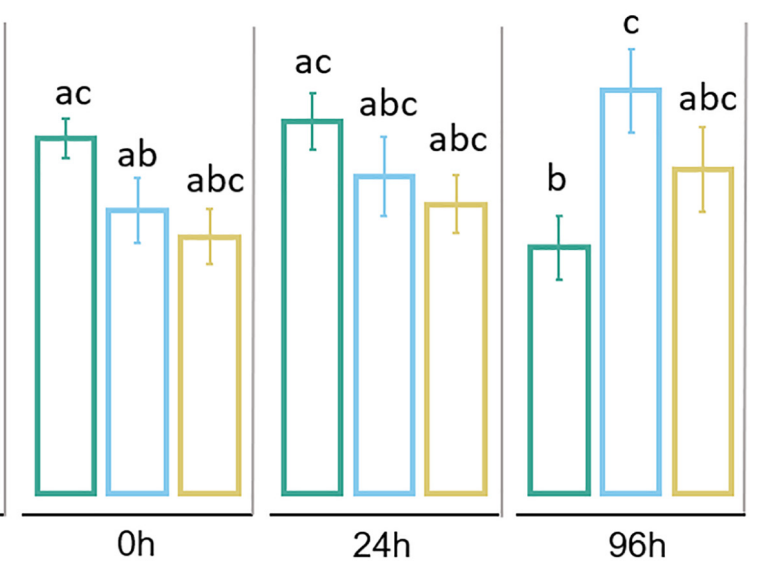

FIGURE 4 | Resting metabolic rate of GT (A) and PC (B) in SW, DSW and N at T-1h, T1h, T24h, and T96h exposure. Values are mean \pm SE. Different letters indicate significant two-way interaction effects of treatment and time after Wald Chi-square test and pairwise multiple comparisons (Bonferroni corrected).

transporters). With ammonia-N in DSW, GT may exhibit lower NKA activity, as reported in the blue swimmer crab Portunus pelagicus exposed to ammonia- $\mathrm{N}$ at low $\mathrm{Na}^{+} / \mathrm{K}^{+}$ratio (Romano and Zeng, 2011), leading to lower $\mathrm{Na}^{+}$levels in the hemolymph compared to PC. A possible explanation could be that PC may better cope with high levels of ammonia-N in its hemolymph than GT, by maintaining the activity level of its membrane transporters. Measuring ammonia- $\mathrm{N}$, ion concentration and $\mathrm{pH}$ levels in the hemolymph would help to confirm this hypothesis.

\section{Implications of Osmoregulation Strategies in the Whole Metabolism of Both Species}

Increased energy expenditure for osmoregulation and ammonia$\mathrm{N}$ excretion may be reflected by increased metabolic indicators such as oxygen consumption (Gomez-Jimenez et al., 2004).

Our results showed no effects of DSW in respiration rate of GT across the $96 \mathrm{~h}$ of exposition compared to the controls in
DSW. In PC, respiration rate progressively increases in DSW, whereas $\mathrm{O}_{2}$ consumption in SW progressively decreased until $96 \mathrm{~h}$ of exposure. Euryhaline crabs are able to compensate for diffusion loss of ions in dilute media by active uptake of gill epithelium (Genovese et al., 2004). The most energy-demanding ion transport mechanism is the active transport driven by the NKA (Lucu and Towle, 2003), with active ion pumping in specialized epithelial cells that are also mitochondria rich (Freire et al., 2008; McNamara and Faria, 2012). Ammonia$\mathrm{N}$ excretion and hyper-osmoregulation mainly rely on these mechanisms (Weihrauch et al., 2004) which generally increases when estuarine/marine crustaceans are exposed to diluted seawater (reviewed in Romano and Zeng, 2012). Based on the large loss of salt in diluted media, these crustaceans must invest considerable amounts of energy in active transport/uptake of salt in order to compensate for the large rates of diffusive salt loss (Henry et al., 2012). When osmotic stress is coupled with ammonia- $\mathrm{N}$ stress, an increase in $\mathrm{O}_{2}$ consumption is observed in GT after $96 \mathrm{~h}$ exposure, but this was not observed in PC. 


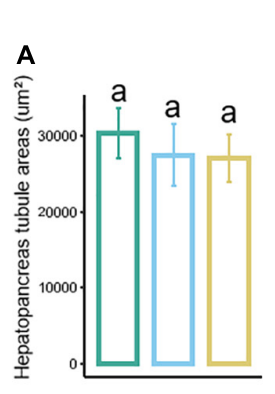

C

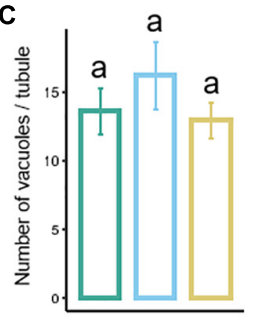

Europa : G. tetragonon

D

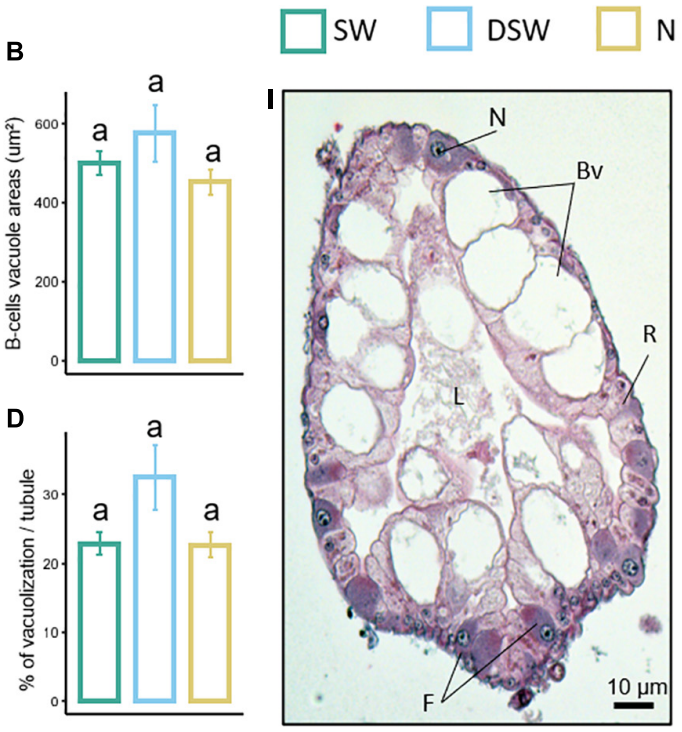

E
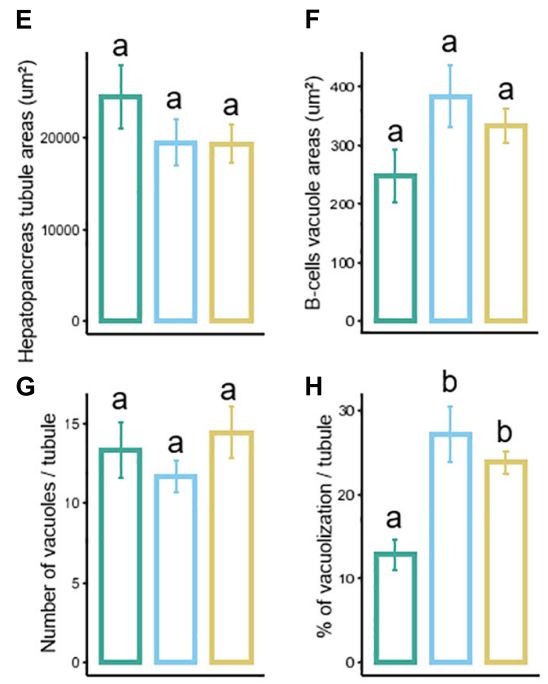

Mayotte : P. chlorophthalmus

FIGURE 5 | Histological analyses from transverse sections of different tubules of GT (A-D) and PC (E-H) hepatopancreas exposed to seawater (SW), diluted seawater (DSW) and $10 \mathrm{mg} \cdot \mathrm{L}^{-1}$ ammonia-N (N). Measurements and counts were carried out on randomly distributed tubules per individual. Data were averaged per individual. (A,E) Areas of the tubules expressed as mean per individual; (B,F) B-cell vacuole areas expressed as mean per tubule per individual; (C,G) number of B-cell vacuoles in the tubule; (D,H) percentage of B-cell vacuolization area per tubule; (I) light microscopy illustration of a tubule cross section (GT). The photograph shows a tubule epithelium containing absorbing R-cells (R), enzyme synthetizing F-cells (F), and tubule-clearing B-cells (Bv). L, lumen; N, nucleus. Values are means $\pm \operatorname{SEM}(N=3-8$ per treatment). Different letters represent statistically significant differences between treatments at $p<0.05$ after Wald Chi-square test and multiple comparisons (Tukey).

This could be directly linked to the OC decrease observed in this species. An increased energy demand is likely to occur in case of ammonia-N prolonged exposure. For instance, GT could rely on different ionic transport mechanisms without necessarily modifying its gill epithelial thickness (as discussed in Section "Histological Changes to Explain Paraleptuca chlorophthalmus and Gelasimus tetragonon Differential Ammonia-N Tolerance"). Even with an increased uptake of $\mathrm{O}_{2}$, it is possible that the maintenance of GT hydromineral balance and ammonia-N excretion function is less efficient when facing these stressors than in PC. This could highlight a physiological trade-off because of the lack of other adaptive mechanisms, but also due to any physiological differences between the two species. In PC maintained in DSW, the increase in $\mathrm{O}_{2}$ uptake could be due to an increased energy demand for osmoregulation (among others). However, a lower oxygen consumption in DSW with ammonia$\mathrm{N}$ could suggest an increased anaerobic metabolism or a different compromise between gas exchange and osmoregulation at the gill surface (aka the osmo-respiratory compromise) (Robertson et al., 2015). A clear functional specialization has been reported for several crab species, posterior gills being the main effectors of the "compensatory" process, while anterior gills are mostly involved in gas exchange (Taylor and Taylor, 1992; Pequeux, 1995; Genovese et al., 2004). Anterior gills are also known to be actively involved in ammonia excretion (Weihrauch et al., 1998, 1999) and in some hyper-regulating species such as green shore crab, active ammonia excretion rates being lower in posterior osmoregulatory gills compared to anterior gills (Weihrauch et al., 1998). These results indicate that osmoregulatory processes are not directly linked to ammonia excretion and that excretion of toxic ammonia could proceed independently of other physiological processes (Weihrauch and O'Donnell, 2017). Large areas in the lamellae of the posterior gill epithelium reveals thick ion-transporting cells with welldeveloped basolateral membranes associated with numerous mitochondria in several species of euryhaline crabs such as Neohelice granulata (previously Chasmagnathus granulatus) (Genovese et al., 2004). Most of the NKA activity is generally restricted to specific areas of posterior gill lamellae lined by this kind of epithelium (Towle and Kays, 1986).

\section{Histological Changes to Explain Paraleptuca chlorophthalmus and Gelasimus tetragonon Differential Ammonia-N Tolerance}

In DSW, no changes were observed in the thickness of the gill epithelium for the two species (Figures 6A,B). However, when exposed to ammonia- $\mathrm{N}$ for $96 \mathrm{~h}$, branchial epithelium thickness of PC significantly increases along the longitudinal axis, whereas this does not occur for GT. An increase in osmoregulatory epithelial patches surface of posterior gills in crabs exposed to either dilute or hyper-saline water (i.e., when crabs osmoregulate) has already been observed (Genovese et al., 2000; Lovett et al., 2006). The authors suggest that these gills could be involved both in active ion uptake and active excretion of ions depending on 
TABLE 1 | Results of analysis of deviance for histological measurements from transverse sections of different hepatopancreas tubules of $G$. tetragonon and $P$. chlorophthalmus as a function of treatment.

\begin{tabular}{|c|c|c|c|c|c|}
\hline A & Hepatop & creas tub & areas $(\mu \mathrm{r}$ & & \\
\hline Factor & DF & & & & \\
\hline & GT-PC & GT & PC & GT & PC \\
\hline Treatment & 2 & 0.9819 & 1.4586 & 0.6121 & 0.4822 \\
\hline
\end{tabular}

\begin{tabular}{|c|c|c|c|c|c|}
\hline \multirow{3}{*}{$\begin{array}{l}\text { B } \\
\text { Factor }\end{array}$} & \multicolumn{5}{|c|}{ Number of vacuoles/tubules } \\
\hline & \multirow{2}{*}{$\frac{\text { DF }}{\text { GT-PC }}$} & \multicolumn{2}{|c|}{$x^{2}$} & \multicolumn{2}{|c|}{$P$} \\
\hline & & GT & PC & GT & PC \\
\hline Treatment & 2 & 1.4951 & 1.3823 & 0.4735 & 0.501 \\
\hline
\end{tabular}

C B-cells vacuole areas $\left(\mu \mathrm{m}^{2}\right)$

\begin{tabular}{lccccccc}
\hline Factor & DF & & \multicolumn{3}{c}{$\chi^{2}$} & & \multicolumn{2}{c}{$\boldsymbol{P}$} \\
\cline { 2 - 4 } \cline { 6 - 7 } & GT-PC & & GT & PC & & GT & PC \\
\hline Treatment & 2 & & 1.0779 & 4.4643 & & 0.5834 & 0.1073 \\
\hline
\end{tabular}

D $\%$ of vacuolization/tubule

\begin{tabular}{|c|c|c|c|c|c|}
\hline \multirow[t]{2}{*}{ Factor } & \multirow{2}{*}{$\frac{\text { DF }}{\text { GT-PC }}$} & \multicolumn{2}{|c|}{$x^{2}$} & \multicolumn{2}{|c|}{$P$} \\
\hline & & GT & PC & GT & PC \\
\hline Treatment & 2 & 3.1161 & 9.5381 & 0.2105 & 0.008489 \\
\hline
\end{tabular}

GT, Gelasimus tetragonon (Europa Island); PC, Paraleptuca chlorophthalmus (Mayotte). Wald Chi-square tests are performed for testing the significant differences of fixed categorical variables in GLMM ( $N=7-8$ per treatment for 3 treatment group). Statistically significant effects are indicated by asterisks: ${ }^{* *} p<0.01$ and appear in bold.

the medium salinity, especially with the progressive increase of NKA activity during 6 days observed in crabs exposed to dilute seawater (Lovett et al., 2006). In PC, this response may be directly related to a strategy allowing increased ammonia- $\mathrm{N}$ excretion and osmoregulation may be through NKA increased activity, as discussed above. By increasing the thickness of the basolateral epithelium of posterior gill cells, PC may increase the number of ion transporters (mainly NKA) and mitochondria allowing, therefore, an increase in its osmoregulatory and ammonia$\mathrm{N}$ excretion capacities. The increase in epithelial thickness does not occur in DSW although a higher metabolic rate is observed in this condition. Therefore, PC could rely on two different strategies depending on the nature and level of stress (increased metabolic rate in DSW and/or enhanced ion transport mechanisms when exposed to ammonium by the lengthening of the basolateral epithelium), whereas GT cannot exhibit such plasticity regarding ammonia- $\mathrm{N}$ exposure and increases its metabolic rate.

However, though not quantified, no major disruption of cellular structure has been observed in either species exposed to DSW or Ammonia-N. In Romano and Zeng (2007b), Ammonia$\mathrm{N}$ exposure for $96 \mathrm{~h}$ lead to different dose-dependent disruptions of gills in $P$. pelagicus. At $10 \mathrm{mg} \cdot \mathrm{l}^{-1}$ ammonia-N (a similar concentration as in the present study), gill lamellae showed
TABLE 2 | Results of analysis of variance for gill epithelial thickness measured on different parts of the longitudinal axis of the gill one-way ANOVAs).

\begin{tabular}{|c|c|c|c|c|c|c|c|c|c|}
\hline \multirow{3}{*}{$\begin{array}{l}\text { A } \\
\text { Factor }\end{array}$} & \multicolumn{9}{|c|}{ Gill epithelial thickness - apical part } \\
\hline & \multicolumn{2}{|c|}{ DF } & \multicolumn{2}{|c|}{ MS } & \multicolumn{2}{|c|}{$\boldsymbol{F}$} & \multicolumn{2}{|r|}{$P$} & \\
\hline & GT & PC & GT & PC & GT & PC & GT & PC & \\
\hline Treatment & 2 & 2 & 0.8836 & 20.635 & 0.551 & 15.36 & 0.579 & 3.68E-06 & 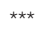 \\
\hline Residuals & 57 & 63 & 1.6029 & 1.343 & & & & & \\
\hline B & Gill & pitheli & ial thickne & ss - cent & ral part & & & & \\
\hline \multirow[t]{2}{*}{ Factor } & \multicolumn{2}{|c|}{ DF } & \multicolumn{2}{|c|}{ MS } & \multicolumn{2}{|c|}{$\boldsymbol{F}$} & \multicolumn{2}{|r|}{$P$} & \\
\hline & GT & PC & GT & PC & GT & PC & GT & PC & \\
\hline Treatment & 2 & 2 & 2.054 & 14.839 & 1.503 & 13.79 & 0.231 & 1.07E-05 & *** \\
\hline Residuals & 57 & 63 & 1.367 & 1.076 & & & & & \\
\hline C & Gill & pitheli & ial thickne & ss - basa & al part & & & & \\
\hline \multirow[t]{2}{*}{ Factor } & \multicolumn{2}{|c|}{ DF } & \multicolumn{2}{|c|}{ MS } & \multicolumn{2}{|c|}{$\boldsymbol{F}$} & \multicolumn{2}{|r|}{$P$} & \\
\hline & GT & PC & GT & PC & GT & PC & GT & PC & \\
\hline Treatment & 2 & 2 & 2.057 & 20.844 & 0.841 & 11.37 & 0.437 & 6.08E-05 & 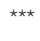 \\
\hline Residuals & 57 & 63 & 2.447 & 1.833 & & & & & \\
\hline $\begin{array}{l}\text { GT, Gel } \\
\text { chlorophthe } \\
N=7-8 p\end{array}$ & $\begin{array}{l}\text { asim } \\
\text { almus } \\
\text { er tre }\end{array}$ & Is & $\begin{array}{l}\text { tetragond } \\
\text { otte). } \\
\text { t for } 3 \text { tr } \\
{ }^{* * *} p<0 .\end{array}$ & atment $\mathrm{g}$ & group. S & Island); & $\begin{array}{l}\text { PC, } \\
\text { signific }\end{array}$ & Paralept & $\begin{array}{l}\text { uca } \\
\text { are }\end{array}$ \\
\hline
\end{tabular}

local infiltrations of hemocytes with normal lamellae structures whereas $60 \mathrm{mg} . \mathrm{l}^{-1}$ ammonia- $\mathrm{N}$ generated extensive hemocyte infiltrations, disrupted pillar cells and lamellae collapses.

In Crustaceans, the hepatopancreas is a key metabolic organ, expressing a variety of transporters (Ahearn et al., 1992). Its numerous tubules are involved in food digestion, detoxification of xenobiotics and nutrient absorption (Ceccaldi, 1998; Zilli et al., 2003; Ortega et al., 2014). Histological analyses of these tubules revealed few changes for the B-cells in both GT and PC (Figures 5A-G). Even if their role is still discussed, B-cells can be considered to have two functions: elimination of waste material and intracellular digestion of nutrients (Vogt, 1994). The supranuclear vacuoles resulting from the coalescence of subapical vacuoles take the form of huge lysosomes (Vogt, 1993) and their content can be discharged into the lumen by holocrine secretions (Nott et al., 1985). Our results showed a higher vacuolization in $\mathrm{PC}$ exposed to Ammonia- $\mathrm{N}$ that could be linked to an increased intracellular digestion process through B-cells vacuoles, as it has been found in a Sesarmid crab species exposed to domestic wastewater (Mégevand et al., 2021). This increase in activity would potentially lead to an increased energy expenditure but in this case, our hypothesis is that ammonia-N could have a limited effect on the hepatopancreas functioning. As mentioned by Chu (1987), the hepatopancreas overall contribution to osmoregulatory ion uptake is believed to be minimal, whereas gills are the main site for respiration, osmoregulation, ammonia- $\mathrm{N}$ excretion, these gills being the main organs involved for the overall organismal adaptation to changing conditions. In Ocypodids such as PC and GT, 


\section{Europa : G. tetragonon}

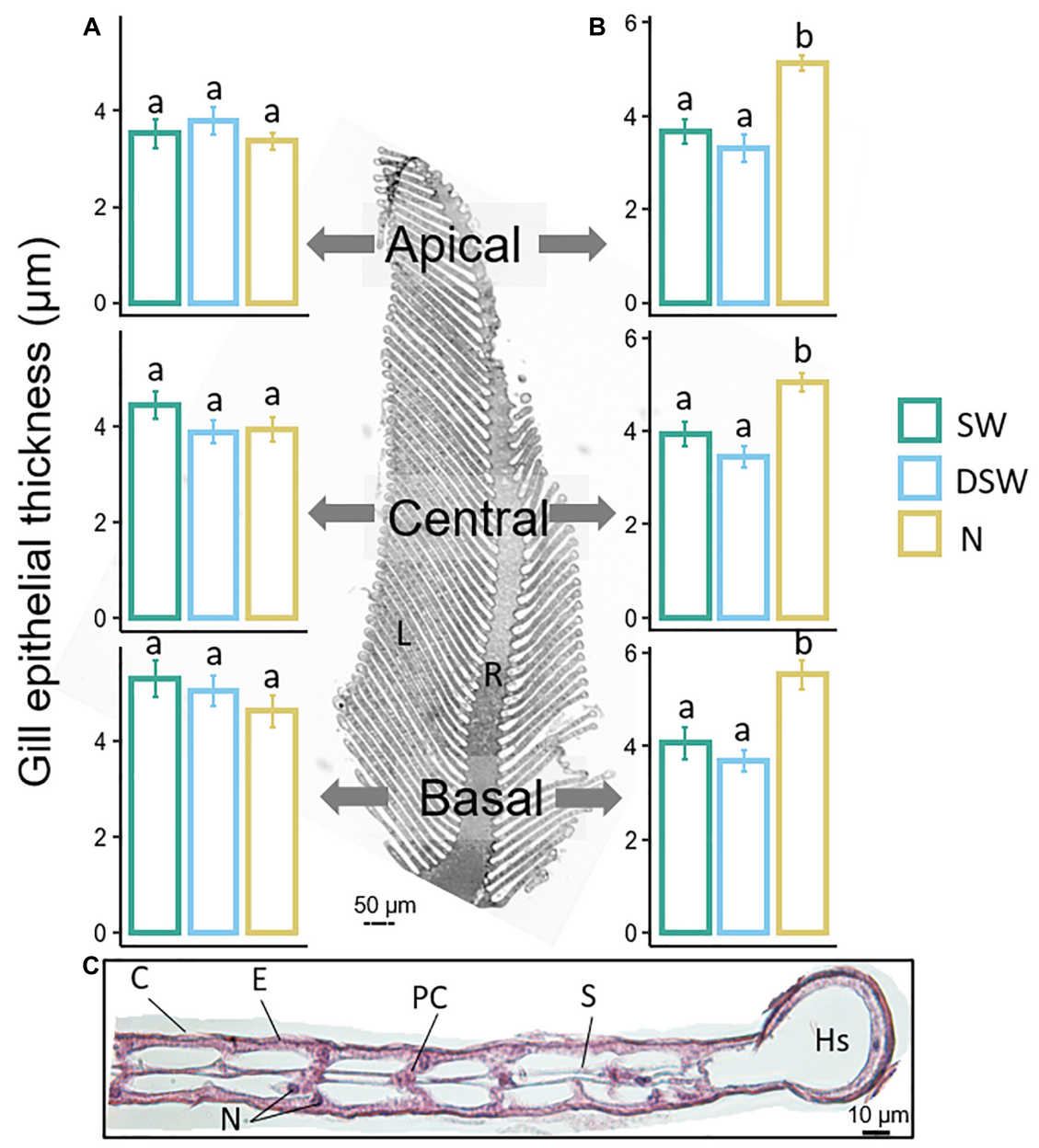

FIGURE 6 | Histological analyses from transverse sections of GT and PC posterior gills exposed to seawater (SW), diluted seawater (DSW) and 10 mg.L ${ }^{-1}$ ammonia-N (N). The photograph illustrates a histological cross section of a posterior gill through the raphe (central part, $R)$ and the lamellae $(\mathrm{L})$. (A,B) Epithelial thickness measurements of gill lamellae across the longitudinal axis of posterior gills of GT and PC. Values are means \pm SEM ( $N=3-8$ per treatment). Different letters represent statistically significant differences between treatments at $p<0.05$ obtained from a one-way ANOVA followed by Tukey post hoc comparisons. (C) Histological section of a gill lamella of Gelasimus tetragonon (cross section). C, cuticle; E, epithelium; N, nucleus; PC, pillar cell; S, septum; Hs, hemocoelic space.

the study of the antennal gland would also be of interest in order to understand ammonia excretion mechanisms. As shown for several fiddler crabs such as Minuca pugnax or Leptuca pugilator, ammonia is known to be actively transported across the duct and excreted in the primary urine which contains a high concentration of ammonium (Green et al., 1959; De Vries et al., 1994). Other ecomorphological markers in addition to those used on the hepatopancreas and gills would be interesting to study as indicators of adaptation to changing environments. For example, Lim and Goh (2021) demonstrated that the setae present on the maxillipeds are great indicators of adaptation, especially for efficient food extraction regarding sediment quality. Fiddler crabs with greater diversity and density in setae could be able to adapt to more variable habitats since their ability to extract food from different sediment types would be better.
Coping with an aquatic environment with low salinity and elevated ammonia-N is highly species- and habitat-specific. Therefore, a fully euryhaline species such as PC, that is adapted to nutrient-rich environments (Gross, 1982; Henry et al., 2012) is likely to be less vulnerable to nutrient enrichment and may be able to develop other coping mechanisms. However, this study focuses on potential short-term acclimation capacities. It does not take into account any possible environmental determinism that could arise from micro-evolution after prolonged exposure to ammonia-N enriched conditions (in Mayotte) or differential abiotic factors such as eutrophic or oligotrophic environments.

A research program with multi-generational expositions of the two populations would be of high interest, especially for understanding ecosystem health and ecological risk implications on a longer timescale (although technically complicated to implement). 


\section{Ecosystem and Risk Assessment Implications}

Acclimatory and adaptive capacities to different environments induce species-specific responses among Decapod crustaceans that rely on various mechanisms to maintain their metabolism (Weihrauch et al., 1999; Henry et al., 2012; Romano and Zeng, 2013).

However, brackish and intertidal environments are among the most stressful aquatic biotopes and the establishment of Crustacean communities in such habitats suppose highly adapted physiological features (Gilles and Pequeux, 1983; Charmantier et al., 2002) to cope with low and varying salinities (Henry et al., 2012), as well as constantly changing environments. For example, it has been shown by Yong and Lim (2021) that ocypodid crabs such as Ocypode gaudichaudii possess a feeding plasticity when confronted to different habitat types, which is related to their burrowing and foraging strategies. In the case of our study, salinity variations and nitrogen enrichment phenomena could also induce different levels of adaptation in feeding and foraging habits, which would be interesting to study in both species in parallel with the individual physiology.

In the present study, PC appears to have a better physiological tolerance to decreased salinity compared to GT, even if GT is a relatively strong osmoregulator (hypothesis 1). Ammonia-N triggers short-term acclimation in PC that was not observed in GT suggesting that this species could be more vulnerable to anthropogenic discharges (hypothesis 2). GT copes with $96 \mathrm{~h}$ ammonia- $\mathrm{N}$ exposure through increased metabolic rate to excrete this product, while struggling to maintain its osmoregulatory balance. However, this response does not occur in DSW condition without ammonia-N. This suggests that some cumulative deleterious effects under Ammonia-N exposure and osmotic stress occur for this species (hypothesis 3 ).

Ammonia-N was used in this study as a first indicator of anthropogenic effluents, but it is more likely that crab communities are confronted with different contaminants with combined effects (e.g., complex and hypoxic wastewater), often consisting of repeated exposures. Worldwide, effects of domestic effluent discharges (controlled or not) on crab community assemblage have been observed in several different mangroves with various results (Wear and Tanner, 2007; Penha-Lopes et al., 2009; Wickramasinghe et al., 2009; Capdeville, 2018). The results of the present study point (at least) to a short-term physiological acclimation to salinity variation and pollution for species such as PC, acclimated to euryhaline and anthropized conditions (already proposed in Mégevand et al., 2021, submitted), but it has been demonstrated that individual abundance for this species decreased in chronically WW impacted areas (Capdeville et al., 2018). If GT is unable to develop short-term response to salinity and ammonia- $\mathrm{N}$ inputs, it is likely that this species would be even more sensitive to longer exposure to pollution, or to more complex contaminants such as hypoxic WW. If the population decline of engineering species can be dreadful for the functioning of freshwater-influenced mangroves (e.g., Mayotte), what about isolated and pristine ecosystems like Europa Island? What would be the acclimation potential of representative species like GT in the event of anthropogenic effluents? In view of the results obtained in this study and those obtained during the various works mentioned above, it is possible to be pessimistic about the ecosystem risks incurred by a pristine mangrove such as that of Europa if it were to face waters discharges of anthropogenic origin.

\section{CONCLUSION}

The two crab species studied here showed different physiological plasticity that led to different tolerance to salinity variations and ammonia- $\mathrm{N}$ exposure. In accordance with our first hypothesis, P. chlorophthalmus (Mayotte Island) has a better osmoregulatory capacity in diluted seawater than G. tetragonon (Europa Island), which remains, however, a strong hyper-hypo-osmoregulator. Exposure for $96 \mathrm{~h}$ to ammonia-N at a concentration of $10 \mathrm{mg} . \mathrm{l}^{-1}$ in diluted seawater (5pt) generates branchial morphological acclimation in PC most likely in order to increase the osmoregulatory and Ammonia-N excretion functions. These changes do not occur in GT, this species experiencing an increase in oxygen consumption over time as its osmoregulatory capacity decreases (hypothesis 2). The two species do not have the same tolerance to short-term nitrogen inputs (as a simulation of anthropogenic presence) (hypothesis 3). Burrowing crabs ensure crucial ecological functions associated with their bioturbation activity. A change in crab community composition will not ensure the maintenance of these functions as functional redundancy may not happen. Consequences in terms of mangrove functioning and vulnerability are difficult to predict and linked to many others parameters. However, our study emphasizes the importance of considering small/medium scale ecophysiological indicators of species vulnerability, especially when developed in engineer species, to answer large-scale questions of ecosystem risk assessment.

\section{DATA AVAILABILITY STATEMENT}

The original contributions presented in the study are included in the article/Supplementary Material, further inquiries can be directed to the corresponding author.

\section{AUTHOR CONTRIBUTIONS}

LM: conceptualization, methodology, investigation, formal analysis, and writing - original draft. DT: conceptualization, methodology, investigation (osmoregulation curves and osmoregulatory capacity), formal analysis, and writing - review and editing. CL'É: investigation (histological analyzes). SH: methodology (histological analyzes), investigation (histological analyzes), and writing - review and editing. EC: methodology, investigation (molecular analysis of rRNA sequences), and writing - review and editing. TLH: investigation (histological experiments) and writing - review and editing. J-HL: supervision, conceptualization, investigation, and writing - review and editing. ES: project administration, funding acquisition, 
supervision, conceptualization, investigation, and writing review and editing. All authors contributed to the article and approved the submitted version.

\section{ACKNOWLEDGMENTS}

The authors are grateful to the Terres Australes et Antarctiques Françaises (TAAF) for allowing scientific activities including crab

\section{REFERENCES}

Ahearn, G. A., Gerencser, G., Thamotharan, M., Behnke, R., and Lemme, T. (1992). Invertebrate gut diverticula are nutrient absorbing organs. Am. J. Physiol 263, R472-R478. doi: 10.1152/ajpregu.1992.263.3.R472

Alongi, D. M. (2002). Present state and future of the world's mangrove forests. Environ. Conserv. 29, 331-349. doi: 10.1017/S0376892902000231

Amaral, V., Penha-Lopes, G., and Paula, J. (2009). Effects of vegetation and sewage load on mangrove crab condition using experimental mesocosms. Estuar. Coast. Shelf Sci. 84, 300-304. doi: 10.1016/j.ecss.2009.07.007

Azpeitia, E., Vanegas-Pérez, C., Moreno-Sáenz, E., Betancourt-Lozano, M., and Miranda-Anaya, M. (2013). Effect of chronic ammonia exposure on locomotor activity in the fiddler crab Uca princeps upon artificial tides and light cycles. Biol. Rhythm Res. 44, 113-123. doi: 10.1080/09291016.2011.652864

Barbieri, E., Bondioli, A. C. V., de Melo, C. B., and Henriques, M. B. (2016). Nitrite toxicity to Litopenaeus schmitti (Burkenroad, 1936, Crustacea) at different salinity levels. Aquac. Res. 47, 1260-1268. doi: 10.1111/are.12583

Bermudes, M., and Ritar, A. J. (2008). Tolerance for ammonia in early stage spiny lobster (Jasus edwardsii) phyllosoma larvae. J. Crustac. Biol. 28, 695-699. doi: 10.1651/08-2994.1

Borges, F. O., Sampaio, E., Figueiredo, C., Rosa, R., and Grilo, T. F. (2018). Hypercapnia-induced disruption of long-distance mate-detection and reduction of energy expenditure in a coastal keystone crustacean. Physiol. Behav. 195, 69-75. doi: 10.1016/j.physbeh.2018.07.023

Bouchard, J.-M., Poupin, J., Cleva, R., Dumas, J., and Dinhut, V. (2013). Land, mangrove and freshwater decapod crustaceans of Mayotte region (Crustacea. Decapoda). Atoll Res. Bull. 592, 1-69. doi: 10.5479/si.00775630.592

Boullet, V. (2014). The vegetation of the island of Europa (channel of Mozambique). 1- salt marshes and steppes. Doc. Phytosociol. 1, 501-535.

Briscoe, N. J., Porter, W. P., Sunnucks, P., and Kearney, M. R. (2012). Stagedependent physiological responses in a butterfly cause non-additive effects on phenology. Oikos 121, 1464-1472. doi: 10.1111/j.1600-0706.2011.20049.x

Brodie, J. F., Redford, K. H., and Doak, D. F. (2018). Ecological function analysis: incorporating species roles into conservation. Trends Ecol. Evol. 33, 840-850. doi: 10.1016/j.tree.2018.08.013

Brooks, M. E., Kristensen, K., van Benthem, K. J., Magnusson, A., Berg, C. W., Nielsen, A., et al. (2017). glmmTMB balances speed and flexibility among packages for zero-inflated generalized linear mixed modeling. $R$ J. 9, 378-400. doi: 10.32614/rj-2017-066

Burger, J. (2006). Bioindicators: a review of their use in the environmental literature 1970-2005. Environ. Bioindic. 1, 136-144. doi: 10.1080/15555270600701540

Cannicci, S., Bartolini, F., Dahdouh-Guebas, F., Fratini, S., Litulo, C., Macia, A., et al. (2009). Effects of urban wastewater on crab and mollusc assemblages in equatorial and subtropical mangroves of East Africa. Estuar. Coast. Shelf Sci. 84, 305-317. doi: 10.1016/j.ecss.2009.04.021

Capdeville, C. (2018). Évaluation des Capacités de Résistance et de Résilience de L'écosystème Mangrove en Réponse à des Apports D'eaux Usées Domestiques Prétraitées. Toulouse: Université de Toulouse.

Capdeville, C., Abdallah, K., Buffan-Dubau, E., Lin, C., Azemar, F., Lambs, L., et al. (2018). Limited impact of several years of pretreated wastewater discharge on fauna and vegetation in a mangrove ecosystem. Mar. Pollut. Bull. 129, 379-391. doi: 10.1016/j.marpolbul.2018.02.035

Ceccaldi, H. J. (1998). A synopsis of the morphology and physiology of the digestive system of some crustacean species studied in France. Rev. Fish. Sci. 6, 13-39. doi: $10.1080 / 10641269891314177$ sampling in the Scattered Islands and providing logistical support during the scientific cruise and our stay on Europa Island.

\section{SUPPLEMENTARY MATERIAL}

The Supplementary Material for this article can be found online at: https://www.frontiersin.org/articles/10.3389/fevo.2022. 839160/full\#supplementary-material

Charmantier, G., Giménez, L., Charmantier-Daures, M., and Anger, K. (2002). Ontogeny of osmoregulauon, physiological plasticity and larval export strategy in the grapsid crab Chasmagnathus granulata (Crustacea, Decapoda). Mar. Ecol. Prog. Ser. 229, 185-194. doi: 10.3354/meps229185

Chen, J. C., and Chen, C. T. (1996). Changes of osmotic and electrolyte concentrations in the haemolymph of Penaeus japonicus exposed to ambient ammonia. Comp. Biochem. Physiol. C Pharmacol. Toxicol. Endocrinol. 114, 35-38. doi: 10.1016/0742-8413(95)02110-8

Chu, K. H. (1987). Sodium transport across the perfused midgut and hindgut of the blue crab, Callinectes sapidus: the possible role of the gut in crustacean osmoregulation. Comp. Biochem. Physiol. A Physiol. 87, 21-25. doi: 10.1016/ 0300-9629(87)90418-X

Chuine, I. (2010). Why does phenology drive species distribution? Philos. Trans. $R$. Soc. B Biol. Sci. 365, 3149-3160. doi: 10.1098/rstb.2010.0142

Clark, T. D., Sandblom, E., and Jutfelt, F. (2013). Aerobic scope measurements of fishes in an era of climate change: respirometry, relevance and recommendations. J. Exp. Biol. 216, 2771-2782. doi: 10.1242/jeb. 084251

Coggan, N. V., Hayward, M. W., and Gibb, H. (2018). A global database and "state of the field" review of research into ecosystem engineering by land animals. J. Anim. Ecol. 87, 974-994. doi: 10.1111/1365-2656.12819

Crane, J. (1975). Fiddler crabs of the world: Ocypididae: Genus Uca. New Jersey: Princeton University press. doi: 10.1016/0003-3472(78)90130-6

Dawn, W., and Frith, C. B. (1977). Observations on fiddler crabs (Ocypodidae: genus Uca) on Surin Island, western peninsular Thailand, with particular reference to Uca tetragonon (Herbst). Res. Bull. Phuket Mar. Biol. Cent. 18:14.

De Freitas Rebelo, M., Rodriguez, E. M., Santos, E. A., and Ansaldo, M. (2000). Histopathological changes in gills of the estuarine crab Chasmagnathus granulata (Crustacea-Decapoda) following acute exposure to ammonia. Comp. Biochem. Physiol. C Pharmacol. Toxicol. Endocrinol. 125, 157-164. doi: 10.1016/ S0742-8413(99)00093-6

De Lange, H. J., Sala, S., Vighi, M., and Faber, J. H. (2010). Ecological vulnerability in risk assessment - A review and perspectives. Sci. Total Environ. 408, 38713879. doi: 10.1016/j.scitotenv.2009.11.009

De Vries, M. C., Wolcott, D. L., and Holliday, C. W. (1994). High Ammonia and Low $\mathrm{pH}$ in the Urine of the Ghost Crab. Ocypode quadrata. Biol. Bull. 186, 342-348. doi: 10.2307/1542280

Dittmann, S. (1996). Effects of macrobenthic burrows on infaunal communities in tropical tidal flats. Mar. Ecol. Prog. Ser. 134, 119-130. doi: 10.3354/meps134119

Emmerson, W. D., and McGwynne, L. E. (1992). Feeding and assimilation of mangrove leaves by the crab Sesarma meinerti de Man in relation to leaf-litter production in Mgazana, a warm-temperate southern African mangrove swamp. J. Exp. Mar. Bio. Ecol. 157, 41-53. doi: 10.1016/0022-0981(92)90073-J

Fox, J., and Weisberg, S. (2019). An R Companion to Applied Regression, 3rd. Edn. Thousand Oaks, CA: Sage.

Freire, C. A., Onken, H., and McNamara, J. C. (2008). A structure-function analysis of ion transport in crustacean gills and excretory organs. Comp. Biochem. Physiol. A Mol. Integr. Physiol. 151, 272-304. doi: 10.1016/j.cbpa.2007.05.008

Galloway, J. N., Townsend, A. R., Erisman, J. W., Bekunda, M., Cai, Z., Freney, J. R., et al. (2008). Transformation of the nitrogen cycle: recent trends, questions, and potential solutions. Science 320, 889-892. doi: 10.1126/science.1136674

Genovese, G., Luchetti, C. G., and Luquet, C. M. (2004). Na+/K+-ATPase activity and gill ultrastructure in the hyper-hypo-regulating crab Chasmagnathus granulatus acclimated to dilute, normal, and concentrated seawater. Mar. Biol. 144, 111-118. doi: 10.1007/s00227-003-1169-6 
Genovese, G., Luquet, C. M., Paz, D. A., Rosa, G. A., and Pellerano, G. N. (2000). The morphometric changes in the gills of the estuarine crab Chasmagnathus granulatus under hyper- and hyporegulation conditions are not caused by proliferation of specialised cells. J. Anat. 197, 239-246. doi: 10.1017/ S0021878299006615

Giddins, R., Lucas, J., Neilson, M., and Richards, G. (1986). Feeding ecology of the mangrove crab. Mar. Ecol. Prog. Ser. 33, 147-155.

Gilles, R., and Pequeux, A. (1983). "Interactions of chemical and osmotic regulation with the environment," in The Biology of Crustacea, Environmental Adaptations, Vol. 8, eds D. E. Bliss and W. B. Vernberg (New York, NY: Academic Press), 109-177.

Gillikin, D. P., de Grave, S., and Tack, J. F. (2003). The occurrence of the semiterrestrial shrimp Merguia oligodon (De Man, 1888) in Neosarmatium smithi H. Milne Edwards, 1853 burrows in Kenyan mangroves. Crustaceana 74, 505-507. doi: $10.1163 / 156854001750243081$

Gomez-Jimenez, S., Urias-Reyes, A. A., Vazquez-Ortiz, F., and HernandezWatanabe, G. (2004). Ammonia efflux rates and free amino acid levels in Litopenaeus vannamei postlarvae during sudden salinity changes. Aquaculture 233, 573-581. doi: 10.1016/j.aquaculture.2003.09.050

Gonçalves, R. R., Masui, D. C., McNamara, J. C., Mantelatto, F. L. M., Garçon, D. P., Furriel, R. P. M., et al. (2006). A kinetic study of the gill (Na+, K+)-ATPase, and its role in ammonia excretion in the intertidal hermit crab, Clibanarius vittatus. Comp. Biochem. Physiol. A Mol. Integr. Physiol. 145, 346-356. doi: 10.1016/j.cbpa.2006.07.007

Green, J. W., Harsch, M., Barr, L., and Prosser, C. L. (1959). The regulation of water and salt by the fiddler crabs, Uca Pugnax and Uca Pugilator. Biol. Bull. 116, 76-87. doi: 10.2307/1539157

Gross, M. G. (1982). Oceanography: a View of the Earth, 3rd. Edn. Englewood Cliffs, NJ: Prentice-Hall

Harris, R., Coley, S., Collins, S., and McCabe, R. (2001). Ammonia uptake and its effects on ionoregulation in the freshwater crayfish Pacifastacus leniusculus (Dana). J. Comp. Physiol. B Biochem. Syst. Environ. Physiol. 171, 681-693. doi: $10.1007 /$ s003600100219

Haywood, G. P. (1983). Ammonia toxicity in teleost fishes?: a review. Can. Tech. Rep. Fish. Aquat. Sci. 1177:35.

Henry, R. P., Lucu, Č, Onken, H., and Weihrauch, D. (2012). Multiple functions of the crustacean gill: osmotic/ionic regulation, acid-base balance, ammonia excretion, and bioaccumulation of toxic metals. Front. Physiol 3:431. doi: 10. 3389/fphys.2012.00431

Herteman, M. (2010). Evaluation des Capacités Bioremédiatrices d'une Mangrove Impactée par des Eaux usées Domestiques. Application au site Pilote de Malamani, Mayotte. Doctoral thesis. Toulouse: University of Toulouse

Ikeda, T. (2016). Routine metabolic rates of pelagic marine fishes and cephalopods as a function of body mass, habitat temperature and habitat depth. J. Exp. Mar. Bio. Ecol. 480, 74-86. doi: 10.1016/j.jembe.2016.03.012

Ippolito, A., Sala, S., Faber, J. H., and Vighi, M. (2010). Ecological vulnerability analysis: a river basin case study. Sci. Total Environ. 408, 3880-3890. doi: 10.1016/j.scitotenv.2009.10.002

Jeanson, M., Dolique, F., Anthony, E. J., and Aubry, A. (2019). Decadal-scale dynamics and morphological evolution of mangroves and beaches in a reeflagoon complex, mayotte Island. J. Coast. Res. 88, 195-208. doi: 10.2112/SI88015.1

Johnson, P. C. D., Barry, S. J. E., Ferguson, H. M., and Müller, P. (2015). Power analysis for generalized linear mixed models in ecology and evolution. Methods Ecol. Evol. 6, 133-142. doi: 10.1111/2041-210X.12306

Jones, C. G., Lawton, J. H., and Shachak, M. (1994). Organisms as ecosystem engineers. Oikos 69, 373-386. doi: 10.1353/pbm.2003.0003

Juhel, J. B., Maire, E., Sucré, E., Cheutin, M. C., Marques, V., Benkwitt, C., et al. (2019). From the cradle to the grave: green turtle hatchlings (Chelonia mydas) preyed upon by two-spots red snappers (Lutjanus bohar). Food Webs 21, e00129. doi: 10.1016/j.fooweb.2019.e00129

Killen, S. S. (2014). Growth trajectory influences temperature preference in fish through an effect on metabolic rate. J. Anim. Ecol. 83, 1513-1522. doi: 10.1111/ 1365-2656.12244

Koga, T., Murai, M., Goshima, S., and Poovachiranon, S. (2000). Underground mating in the fiddler crab Uca tetragonon: the association between female life history traits and male mating tactics. J. Exp. Mar. Bio. Ecol. 248, 35-52. doi: 10.1016/S0022-0981(00)00154-4
Kristensen, E. (2008). Mangrove crabs as ecosystem engineers; with emphasis on sediment processes. J. Sea Res. 59, 30-43. doi: 10.1016/j.seares.2007.0 5.004

Kristensen, E., and Alongi, D. M. (2006). Control by fiddler crabs (Uca vocans) and plant roots (Avicennia marina) on carbon, iron, and sulfur biogeochemistry in mangrove sediment. Limnol. Oceanogr. 51, 1557-1571. doi: 10.4319/lo.2006.51. 4.1557

Kristensen, E., Penha-Lopes, G., Delefosse, M., Valdemarsen, T., Quintana, C. O., and Banta, G. T. (2012). What is bioturbation? the need for a precise definition for fauna in aquatic sciences. Mar. Ecol. Prog. Ser. 446, 285-302. doi: 10.3354/ meps09506

Lagarde, R., Teichert, N., Valade, P., and Ponton, D. (2021). Structure of small tropical island freshwater fish and crustacean communities: a niche-or dispersal-based process? Biotropica 53, 243-254. doi: 10.1111/btp.12865

Lambs, L., Mangion, P., Mougin, E., and Fromard, F. (2016). Water cycle and salinity dynamics in the mangrove forests of europa and juan de nova islands, Southwest Indian ocean. Rapid Commun. Mass Spectrom. 30, 311-320. doi: $10.1002 / \mathrm{rcm} .7435$

Lapègue, J. (1999). Aspects Quantitatifs Et Qualitatifs De La Pluviométrie Dans Deux Enjeux Majeurs De La Problématique De L'eau À Mayotte: La Ressource Hydrique, Lassainissemnt Pluvial Et L'érosion. Saint-denis cedex: Université de La Réunion.

Larsen, E. H., Deaton, L. E., Onken, H., O’Donnell, M., Grosell, M., Dantzler, W. H., et al. (2014). Osmoregulation and excretion. Compr. Physiol. 4, 405-573. doi: $10.1002 /$ cphy.c130004

Lee, S. Y. (1997). Potential trophic importance of the faecal material of the mangrove sesarmine crab Sesarma masse. Mar. Ecol. Prog. Ser. 159, 275-284. doi: 10.3354/meps159275

Lemarié, G., Dosdat, A., Covès, D., Dutto, G., Gasset, E., and Person-Le Ruyet, J. (2004). Effect of chronic ammonia exposure on growth of European seabass (Dicentrarchus labrax) juveniles. Aquaculture 229, 479-491. doi: 10.1016/ S0044-8486(03)00392-2

Lenth, R. V. (2016). Least-squares means: the R package lsmeans. J. Stat. Softw 69, 1-33. doi: 10.18637 /jss.v069.i01

Lignot, J.-H., Spanings-Pierrot, G., and Charmantier, G. (2000). Osmoregulatory capacity as a tool in monitoring the physiological condition and the effect of stress in crustaceans. Aquaculture 191, 209-245.

Lim, S. S. L., and Goh, S. J. A. (2021). Ecomorphological adaptations of second maxilliped-setation: insights from three species of fiddler crabs from Panama. Zool. Stud. 60, 48. doi: 10.6620/ZS.2021.60-48

Lin, H. C., Su, Y. C., and Su, S. H. (2002). A comparative study of osmoregulation in four fiddler crabs (Ocypodidae: Uca). Zoolog. Sci. 19, 643-650. doi: 10.2108/ zsj. 19.643

Lovett, D. L., Colella, T., Cannon, A. C., Lee, D. H., Evangelisto, A., Muller, E. M., et al. (2006). Effect of salinity on osmoregulatory patch epithelia in gills of the blue crab Callinectes sapidus. Biol. Bull. 210, 132-139. doi: 10.2307/4134602

Lovett, D. L., Verzi, M. P., Clifford, P. D., and Borst, D. W. (2001). Hemolymph levels of methyl farnesoate increase in response to osmotic stress in the green crab, Carcinus maenas. Comp. Biochem. Physiol. A Mol. Integr. Physiol. 128, 299-306. doi: 10.1016/S1095-6433(00)00308-1

Lucu, Č, and Towle, D. W. (2003). Na++K+-ATPase in gills of aquatic crustacea. Comp. Biochem. Physiol. A Mol. Integr. Physiol 135, 195-214. doi: 10.1016/ S1095-6433(03)00064-3

Lugendo, B. R., and Kimirei, I. A. (2021). Anthropogenic nitrogen pollution in mangrove ecosystems along Dar es Salaam and Bagamoyo coasts in Tanzania. Mar. Pollut. Bull. 168, 112415. doi: 10.1016/j.marpolbul.2021.112415

Manning, C. (2007). Generalized Linear Mixed Models illustrated with R 1-40. Available online at: https://nlp.stanford.edu/manning/courses/ling289/GLMM. pdf [accessed on November 23, 2007].

Martoja, R., and Martoja-Pierson, M. (1967). Initiation aux Techniques de L'histologie Animale. Paris: Masson Cie, 343.

Masui, D. C., Furriel, R. P. M., McNamara, J. C., Mantelatto, F. L. M., and Leone, F. A. (2002). Modulation by ammonium ions of gill microsomal $(\mathrm{Na}+, \mathrm{K}+)-$ ATPase in the swimming crab Callinectes danae: a possible mechanism for regulation of ammonia excretion. Comp. Biochem. Physiol. C Toxicol. Pharmacol. 132, 471-482. doi: 10.1016/S1532-0456(02)00110-2

Masui, D. C., Mantelatto, F. L. M., McNamara, J. C., Furriel, R. P. M., and Leone, F. A. (2009). Na+, K+-ATPase activity in gill microsomes from the blue crab, 
Callinectes danae, acclimated to low salinity: novel perspectives on ammonia excretion. Comp. Biochem. Physiol. A Mol. Integr. Physiol. 153, 141-148. doi: 10.1016/j.cbpa.2009.01.020

McNamara, J. C., and Faria, S. C. (2012). Evolution of osmoregulatory patterns and gill ion transport mechanisms in the decapod Crustacea: a review. J. Comp. Physiol. B Biochem. Syst. Environ. Physiol. 182, 997-1014. doi: 10.1007/s00360012-0665-8

Mégevand, L., Martínez-Alarcón, D., Theuerkauff, D., Rivera-Ingraham, G. A., Lejeune, M., Lignot, J.-H., et al. (2021). The hepatopancreas of the mangrove crab Neosarmatium africanum: a possible key to understanding the effects of wastewater exposure (Mayotte Island, Indian Ocean). Environ. Sci. Pollut. Res. 28, 60649-60662. doi: 10.1007/s11356-021-14892-5

Nagelkerken, I., Blaber, S. J. M., Bouillon, S., Green, P., Haywood, M., Kirton, L. G., et al. (2008). The habitat function of mangroves for terrestrial and marine fauna: a review. Aquat. Bot. 89, 155-185. doi: 10.1016/j.aquabot.2007.12.007

Nixon, S. W. (1995). Coastal marine eutrophication: a definition, social causes, and future concerns. Ophelia 41, 199-219. doi: 10.1080/00785236.1995.10422044

Nixon, S. W., Ammerman, J. W., Atkinson, L. P., Pilson, M. E. Q., and Seitzinger, S. P. (1996). The fate of nitrogen and phosphorus at the land-sea margin of the North Atlantic Ocean. Biogeochemistry 35, 141-180. doi: 10.1007/978-94-0091776-7_4

Nott, J. A., Corner, E. D. S., Marvin, L. J., and O'Hara, S. C. M. (1985). Cyclical contributions of the digestive epithelium to faecal pellet formation by the copepod Calanus helgolandicus. Mar. Biol. 89, 271-279. doi: 10.1007/ BF00393661

O’Donnell, J. L., Beldade, R., Mills, S. C., Williams, H. E., and Bernardi, G. (2017). Life history, larval dispersal, and connectivity in coral reef fish among the Scattered Islands of the Mozambique Channel. Coral Reefs 36, 223-232. doi: 10.1007/s00338-016-1495-z

Ombres, E. H., Donnelly, J., Clarke, M. E., Harms, J. H., and Torres, J. J. (2011). Aerobic and anaerobic enzyme assays in Southern California Rockfish: Proxies for physiological and ecological data. J. Exp. Mar. Bio. Ecol. 399, 201-207. doi: 10.1016/j.jembe.2010.11.007

Ortega, P., Custódio, M. R., and Zanotto, F. P. (2017). Characterization of cadmium transport in hepatopancreatic cells of a mangrove crab Ucides cordatus : the role of calcium. Aquat. Toxicol. 188, 92-99. doi: 10.1016/j.aquatox.2017.04.012

Ortega, P., Santos, R. A., Lacouth, P., Rozas, E. E., Custódio, M. R., and Zanotto, F. P. (2014). Caracterização citoquímica de células de brânquias e hepatopâncreas de Ucides cordatus (Crustacea, Brachyura) validado por transporte celular de metais. Iheringia - Ser. Zool. 104, 347-354. doi: 10.1590/ 1678-476620141043347354

Ouyang, X., and Guo, F. (2016). Paradigms of mangroves in treatment of anthropogenic wastewater pollution. Sci. Total Environ. 544, 971-979. doi: 10.1016/j.scitotenv.2015.12.013

Penha-Lopes, G., Bartolini, F., Limbu, S., Cannicci, S., Kristensen, E., and Paula, J. (2009). Are fiddler crabs potentially useful ecosystem engineers in mangrove wastewater wetlands? Mar. Pollut. Bull. 58, 1694-1703. doi: 10.1016/ j.marpolbul.2009.06.015

Pequeux, A. (1995). Osmotic regulation in crustaceans. J. Crustac. Biol. 15, 1-60.

Piggott, J. J., Townsend, C. R., and Matthaei, C. D. (2015). Reconceptualizing synergism and antagonism among multiple stressors. Ecol. Evol. 5, 1538-1547. doi: $10.1002 /$ ece 3.1465

Poupin, J., Zubia, M., Chabanet, P., and Malay, M. (2012). Illustrated checklist of the Decapoda at Europa Island. J. Mar. Sci. 11, 1-25.

Pusineri, C., Barbraud, C., Kiszka, J., Caceres, S., Mougnot, J., Daudin, G., et al. (2014). Capture-mark-recapture modelling suggests an Endangered status for the Mayotte Island (Eastern Africa) population of Indo-Pacific bottlenose dolphins. Endanger. Species Res. 23, 23-33. doi: 10.3354/esr00 555

Rebelo, M. F., Santos, E. A., and Monserrat, J. M. (1999). Ammonia exposure of Chasmagnathus granulata (Crustacea, Decapoda) Dana, 1851: accumulation in haemolymph and effects on osmoregulation. Comp. Biochem. Physiol. A Mol. Integr. Physiol. 122, 429-435. doi: 10.1016/S1095-6433(99)00026-4

Renault, D., Laparie, M., McCauley, S. J., and Bonte, D. (2018). Environmental adaptations, ecological filtering, and dispersal central to insect invasions. Annu. Rev. Entomol. 63, 345-368. doi: 10.1146/annurev-ento-020117-043315

Rivera-Ingraham, G. A., Barri, K., Boël, M., Farcy, E., Charles, A. L., Geny, B., et al. (2016). Osmoregulation and salinity-induced oxidative stress: Is oxidative adaptation determined by gill function? J. Exp. Biol. 219, 80-89. doi: 10.1242/ jeb. 128595

Robertson, L. M., Kochhann, D., Bianchini, A., Matey, V., Almeida-Val, V. F., Val, A. L., et al. (2015). Gill paracellular permeability and the osmorespiratory compromise during exercise in the hypoxia-tolerant Amazonian oscar (Astronotus ocellatus). J. Comp. Physiol. B Biochem. Syst. Environ. Physiol. 185, 741-754. doi: 10.1007/s00360-015-0918-4

Rodgers, G. G., Tenzing, P., and Clark, T. D. (2016). Experimental methods in aquatic respirometry: the importance of mixing devices and accounting for background respiration. J. Fish Biol. 88, 65-80. doi: 10.1111/jfb.12848

Romano, N., and Zeng, C. (2007a). Acute toxicity of ammonia and its effects on the haemolymph osmolality, ammonia-, $\mathrm{pH}$ and ionic composition of early juvenile mud crabs, Scylla serrata (Forskål). Comp. Biochem. Physiol. A Mol. Integr. Physiol. 148, 278-285. doi: 10.1016/j.cbpa.2007.04.018

Romano, N., and Zeng, C. (2007b). Ontogenetic changes in tolerance to acute ammonia exposure and associated gill histological alterations during early juvenile development of the blue swimmer crab, Portunus pelagicus. Aquaculture 266, 246-254. doi: 10.1016/j.aquaculture.2007.01.035

Romano, N., and Zeng, C. (2011). Importance of balanced $\mathrm{Na}+\mathrm{K}+$ ratios for blue swimmer crabs, Portunus pelagicus, to cope with elevated ammonia-N and differences between in vitro and in vivo gill $\mathrm{Na}+/ \mathrm{K}+$-ATPase responses. Aquaculture 318, 154-161. doi: 10.1016/j.aquaculture.2011.05.016

Romano, N., and Zeng, C. (2012). Osmoregulation in decapod crustaceans: implications to aquaculture productivity, methods for potential improvement and interactions with elevated ammonia exposure. Aquaculture 33, 12-23. doi: 10.1016/j.aquaculture.2011.12.035

Romano, N., and Zeng, C. (2013). Toxic effects of ammonia, nitrite, and nitrate to decapod crustaceans: a review on factors influencing their toxicity, physiological consequences, and coping mechanisms. Rev. Fish. Sci. 21, 1-21. doi: 10.1080/10641262.2012.753404

Ros, M., Guerra-García, J. M., Lignot, J. H., and Rivera-Ingraham, G. A. (2021). Environmental stress responses in sympatric congeneric crustaceans: explaining and predicting the context-dependencies of invader impacts. Mar. Pollut. Bull. 170:112621. doi: 10.1016/j.marpolbul.2021.1 12621

Rosenberg, M. S. (2020). A fresh look at the biodiversity lexicon for fiddler crabs (Decapoda: Brachyura: Ocypodidae). part 2: Biogeography. J. Crustac. Biol. 40, 365-383. doi: 10.1093/jcbiol/ruaa029

Rosenberg, M. S., (2014). Contextual cross-referencing of species names for fiddler crabs (genus Uca): an experiment in cyber-taxonomy. PLoS One 9:e101704. doi: 10.1371/journal.pone.0101704

Shchegolkova, N. M., Krasnov, G. S., Belova, A. A., Dmitriev, A. A., Kharitonov, S. L., Klimina, K. M., et al. (2016). Microbial community structure of activated sludge in treatment plants with different wastewater compositions. Front. Microbiol. 7:90. doi: 10.3389/fmicb.2016.00090

Taylor, H., and Taylor, E. (1992). "Microscopic Anatomy of Invertebrates," in Decapod Crustacea. Decapod Crustac, Vol. 10, eds W. Harrison and R. F. Foelix (Hoboken, NJ: Wiley), 203-293. doi: 10.1073/pnas.89.20. 9764

Teets, N. M., and Denlinger, D. L. (2013). Physiological mechanisms of seasonal and rapid cold-hardening in insects. Physiol. Entomol. 38, 105-116. doi: 10. 1111/phen.12019

Theuerkauff, D., Rivera-Ingraham, G. A., Mercky, Y., Lejeune, M., Lignot, J. H., and Sucré, E. (2018a). Effects of domestic effluent discharges on mangrove crab physiology: integrated energetic, osmoregulatory and redox balances of a key engineer species. Aquat. Toxicol. 196, 90-103. doi: 10.1016/j.aquatox.2018.01. 003

Theuerkauff, D., Rivera-ingraham, G. A., Roques, J. A. C., Bertini, M., Lejeune, M., Farcy, E., et al. (2018b). Salinity variation in a mangrove ecosystem?: a physiological investigation to assess potential consequences of salinity disturbances on mangrove crabs. Zool. Stud. 57, 1-16. doi: 10.6620/ZS.2018. 57-36

Thomas, N., Lucas, R., Bunting, P., Hardy, A., Rosenqvist, A., and Simard, M. (1996). Distribution and drivers of global mangrove forest change, 1996-2010. PLoS One 12:e0179302. . doi: 10.1371/journal.pone.0179302

Thurman, C. L. (2004). Unravelling the ecological significance of endogenous rhythms in intertidal crabs. Biol. Rhythm Res. 35, 43-67. doi: 10.1080/ 09291010412331313232 
Towle, D. W., and Kays, W. T. (1986). Basolateral localization of $\mathrm{Na}^{+}+\mathrm{K}^{+}$-ATPase in gill epithelium of two osmoregulating crabs, Callinetes sapidus and Carcinus maenas. J. Exp. Zool. 239, 311-318. doi: 10.1002/jez.1402390302

Ungherese, G., and Ugolini, A. (2009). Sandhopper solar orientation as a behavioural biomarker of trace metals contamination. Environ. Pollut. 157, 1360-1364. doi: 10.1016/j.envpol.2008.11.038

Vasselon, V., Rimet, F., Tapolczai, K., and Bouchez, A. (2017). Assessing ecological status with diatoms DNA metabarcoding: scaling-up on a WFD monitoring network (Mayotte island, France). Ecol. Indicat. 82, 1-12. doi: 10.1016/j.ecolind. 2017.06.024

Vitousek, P. M., Aber, J. D., Howarth, R. W., Likens, G. E., Matson, P. A., Schindler, D. W., et al. (1997). Human alteration of the global nitrogen cycle: sources and consequences. Ecol. Appl. 7, 737-750.

Vogt, G. (1993). Differentiation of B-cells in the Hepatopancreas of the Prawn Penaeus monodon. Acta Zool. 74, 51-60. doi: 10.1111/j.1463-6395.1993. tb01220.x

Vogt, G. (1994). Life-cycle and functional cytology of the hepatopancreatic cells of Astacus astacus (Crustacea, Decapoda). Zoomorphology 114, 83-101. doi: 10.1007/BF00396642

Wang, A. L., Wang, W. N., Wang, Y., Shang, L. X., Liu, Y., and Sun, R. Y. (2003). Effect of dietary vitamin $\mathrm{C}$ supplementation on the oxygen consumption, ammonia- $\mathrm{N}$ excretion and $\mathrm{Na}^{+} / \mathrm{K}^{+}$ATPase of Macrobrachium nipponense exposed to ambient ammonia. Aquaculture 220, 833-841. doi: 10.1016/S00448486(02)00536-7

Wear, R. J., and Tanner, J. E. (2007). Spatio-temporal variability in faunal assemblages surrounding the discharge of secondary treated sewage. Estuar. Coast. Shelf Sci. 73, 630-638. doi: 10.1016/j.ecss.2007.03.008

Weihrauch, D., Becker, W., Postel, U., Luck-Kopp, S., and Siebers, D. (1999). Potential of active excretion of ammonia in three different haline species of crabs. J. Comp. Physiol. B Biochem. Syst. Environ. Physiol. 169, 25-37. doi: $10.1007 / \mathrm{s} 003600050190$

Weihrauch, D., Becker, W., Postel, U., Riestenpatt, S., and Siebers, D. (1998). Active excretion of ammonia across the gills of the shore crab Carcinus maenas and its relation to osmoregulatory ion uptake. J. Comp. Physiol. B Biochem. Syst. Environ. Physiol. 168, 364-376. doi: 10.1007/s003600050156

Weihrauch, D., Morris, S., and Towle, D. W. (2004). Ammonia excretion in aquatic and terrestrial crabs. J. Exp. Biol. 207, 4491-4504. doi: 10.1242/jeb.01308

Weihrauch, D., and O'Donnell, M. (2017). Acid-Base Balance and Nitrogen Excretion in Invertebrates, Acid-Base Balance and Nitrogen Excretion in Invertebrates. Berlin: Springer. doi: 10.1007/978-3-319-39617-0

Weihrauch, D., and O'Donnell, M. J. (2015). Links between osmoregulation and nitrogen-excretion in insects and crustaceans. Integr. Comp. Biol. 55, 816-829. doi: 10.1093/icb/icv013

Weis, J. S., and Weis, P. (2004). Behavior of four species of fiddler crabs, genus Uca, in southeast Sulawesi, Indonesia. Hydrobiologia 523, 47-58. doi: 10.1023/B: HYDR.0000033093.84155.1d

Wickramasinghe, S., Borin, M., Kotagama, S. W., Cochard, R., Anceno, A. J., and Shipin, O. V. (2009). Multi-functional pollution mitigation in a rehabilitated mangrove conservation area. Ecol. Eng. 35, 898-907. doi: 10.1016/j.ecoleng. 2008.12.021

Xiang, H., Li, K., Cao, L., Zhang, Z., and Yang, H. (2020). Impacts of pollution, sex, and tide on the time allocations to behaviours of Uca arcuata in mangroves. Sci. Total Environ. 742:140609. doi: 10.1016/j.scitotenv.2020.14 0609

Yong, A. Y. P., and Lim, S. S. L. (2021). Plasticity of foraging strategies adopted by the painted ghost crab, ocypode gaudichaudii, in response to in situ food resource manipulation experiments. Zool. Stud. 60:37. doi: 10.6620/ZS.2021. 60-37

Young-Lai, W. W., Charmantier-Daures, M., and Charmantier, G. (1991). Effect of ammonia on survival and osmoregulation in different life stages of the lobster Homarus americanus. Mar. Biol. 110, 293-300. doi: 10.1007/BF013 13716

Zhang, K., Liu, H., Li, Y., Xu, H., Shen, J., Rhome, J., et al. (2012). The role of mangroves in attenuating storm surges. Estuar. Coast. Shelf Sci. 10, 11-23. doi: 10.1016/j.ecss.2012.02.021

Zhu, Z., Xiong, G., and Xing, Z. (2005). Impacts of population growth and economic development on the nitrogen cycle in Asia. Sci. China C. Life Sci. 48, 729-737. doi: 10.1007/BF03187113

Zilli, L., Schiavone, R., Scordella, G., Zonno, V., Verri, T., Storelli, C., et al. (2003). Changes in cell type composition and enzymatic activities in the hepatopancreas of Marsupenaeus japonicus during the moulting cycle. J. Comp. Physiol. B Biochem. Syst. Environ. Physiol. 173, 355-363. doi: 10.1007/s00360003-0348-6

Zubia, M., Turquet, J., and Golubic, S., (2016). Benthic cyanobacterial diversity of Iles Eparses (Scattered Islands) in the Mozambique Channel. Acta Oecol. 72, 21-32. doi: 10.1016/j.actao.2015.09.004

Zuur, A. F., Hilbe, J. M., and Ieno, E. N. (2013). A Beginner's Guide to GLM and GLMM with R, Beginner's Guide Series. Newburgh: Highland Statistics Limited.

Conflict of Interest: The authors declare that the research was conducted in the absence of any commercial or financial relationships that could be construed as a potential conflict of interest.

Publisher's Note: All claims expressed in this article are solely those of the authors and do not necessarily represent those of their affiliated organizations, or those of the publisher, the editors and the reviewers. Any product that may be evaluated in this article, or claim that may be made by its manufacturer, is not guaranteed or endorsed by the publisher.

Copyright (c) 2022 Mégevand, Theuerkauff, L'Épine, Hermet, Corse, L'Honoré, Lignot and Sucré. This is an open-access article distributed under the terms of the Creative Commons Attribution License (CC BY). The use, distribution or reproduction in other forums is permitted, provided the original author(s) and the copyright owner(s) are credited and that the original publication in this journal is cited, in accordance with accepted academic practice. No use, distribution or reproduction is permitted which does not comply with these terms. 